\title{
7. NANNOFACIES OF CAPE BASIN AND WALVIS RIDGE SEDIMENTS, LOWER CRETACEOUS TO PLIOCENE (LEG 40) ${ }^{1}$
}

\author{
Denise Noël, Laboratoire de Géologie, Musée National \\ d'Histoire Naturelle, 43 Rue de Buffon 75005 Paris (France). \\ ERA 121: Pétrologie des roches calcaires \\ and \\ Marthe Melguen, Centre Océanologique de Bretagne, \\ B. P. 337,29273 Brest, France
}

\section{INTRODUCTION}

Nannofacies of Leg 40 cores have been studied with two main objectives in mind: (1) describing in detail Lower Cretaceous black shales (mainly from Site 361) and (2) defining carbonate dissolution cycles. For this purpose samples from Sites 360, 361, 362,363, and 364 have been examined using classical analysis methods (grain size, amount of $\mathrm{CaCO}_{3}$, smear slides, etc.), and the Scanning Electron Microscope (SEM). The methods of nannofacies study and interpretation used here were previously described by Noël $(1969,1970)$.

Each sample will first be described in general, then observations will be given. Because of poor induration of the samples, only freshly broken surfaces but no polished surfaces were examined by SEM after coating with gold palladium.

For each drill site, the list of samples studied, their location, age and references to illustrations are given in Tables 1-6. Ages are mainly based on nannoplankton and foraminifer determinations (Chapters 2-4, this volume; Bolli, this volume; Proto-Decima, this volume). We have also found a few nannofossils not observed during previous biostratigraphic studies, which have led us to propose changes in the ages of Cores 33 to 26 of Site 361 .

\section{CAPE BASIN (SITES 360-361)}

Bordered to the south by the Falkland Plateau and to the north by the Walvis Ridge, the Cape Basin is the southernmost basin of the South Atlantic created during drift of the African and American continents. Drilling at Sites 360 and 361 recovered a continuous section more than 2000 meters thick, with an overlap of about 100 meters between the two holes. Ages range from lower Pliocene to Lower Cretaceous. The cores display a large variety of facies which we have studied in detail with the SEM.

Sites 360 and 361 will be presented together in stratigraphic order starting with Site 361, Lower Cretaceous. The main purpose is to shed light on sedimentological and diagenetic processes as deduced from nannofacies study. These data can also be useful to reconstruct the geological history of the basin.

\footnotetext{
'Contribution 526 of the Scientific Department, Centre Océanologique de Bretagne.
}

\section{SITE 361}

Four nannofacies types can be distinguished from paleontological, mineralogical, and structural characteristics. They correspond to the following age intervals: ${ }^{2}$ (1) Lower Aptian (?) to middle/upper Aptian Cores 48-26 (Unit 7 of Chapter 2 and Core 26 of Unit 6); (2) Cretaceous (?) Cores 25 to 13 (Unit 6); (3) Paleocene (?) Cores 12 to 11 (Unit 5); (4) Middle to upper Eocene, Cores 10 to 3 (upper Unit 5 and Unit 4a). Limits are approximate since they correspond to the samples studied. More precise limits would require more detailed sampling of the cores.

\section{Lower-Aptian to Middle/Upper Albian}

Cores 48 to 26 represent about 400 meters of black bituminous shales with grayish green silty beds, especially Cores 44 to 33 which show also very rare calcareous laminations of millimetric size.

\section{Sample Descriptions}

Twenty samples have been studied by SEM:

48-2, 142-144 cm (Plate 1, Figures 1-5)

Bituminous shale, very dark (5Y 2/1), with $9 \%$ $\mathrm{CaCO}_{3}{ }^{3}$ Poorly structured, with large amorphous zones with irregular borders (Plate 1, Figures 1, 2) due to a very fine clay probably impregnated with bitumen. Pyrite is abundant, either as well-crystallized framboids (Plate 1, Figure 5), or dispersed octahedral crystals (Plate 1, Figures 3,4), regular in size and larger than framboids.

Calcareous nannofossil impressions are abundant (Plate 1, Figures 1,2) in the clay-bituminous sediment matrix. These impressions-mostly of placoliths, highly

\footnotetext{
${ }^{2}$ The breakdown based on nannofacies characteristics is slightly different from those based on shipboard macroscopic observations (especially for age intervals 1 and 2) because SEM observations show that the structure of sediment, its fossil content, and the presence of pyrite are comparable from Core 48 to Core 26 . Quite different sedimentary structures, and lack of nannofossils and pyrite begin with Core 25.

${ }^{3} \mathrm{This}$ value of $\mathrm{CaCO}_{3}$ content is the gross value of a several millimeter thick sample taken at Sample $48-2,142-144 \mathrm{~cm}$. But that value has little significance at the nannofacies scale. With the SEM the surface observed is a tiny layer which can have a $\mathrm{CaCO}_{3}$ content much lower or higher than the gross value of the sample analyzed.
} 
TABLE 1

Site 361

\begin{tabular}{|c|c|c|c|}
\hline $\begin{array}{c}\text { Sample } \\
\text { (Interval in } \mathrm{cm} \text { ) }\end{array}$ & $\begin{array}{l}\text { Approximate } \\
\text { Position } \\
\text { in Hole } \\
(\mathrm{m})\end{array}$ & Age & Illustrations \\
\hline $48-2,142-144$ & 1288 & Lower Aptian? & Plate 1, Figures 1 - 5 \\
\hline $43-3,69-70$ & 1204 & Lower Aptian? & \\
\hline $43-3,40-41$ & 1203 & Lower Aptisn? & \\
\hline $33-3,76-77$ & 1071 & Upper Aptian & Plate 2, Figures 1 - 5 \\
\hline $33-3,75-76$ & 1071 & Upper Aptian & \\
\hline $33-3,31-32$ & 1070 & Lower Albian & \\
\hline black layer & & & Plate 3, Figures 1 - 4 \\
\hline white layer & & & Plate 4, Figures 1 - 4 \\
\hline $32-3,119-121$ & 1062 & Lower/upper Albian & Plate 5, Figure 1 \\
\hline $32-1,24-25$ & 1058 & Lower/upper Albian & Plate 5, Figure 2 \\
\hline $31-3,74-76$ & 1052 & Lower/upper Albian & Plate 5, Figures 3, 4 \\
\hline $31-3,59-61$ & 1052 & Lower/upper Albian & Plate 6, Figures 1 - 5 \\
\hline $30-2,57-59$ & 1041 & Lower/upper Albian & (1) \\
\hline $29-5,129-131$ & 1036 & Lower/upper Albian & \\
\hline $29-4,92-94$ & 1034 & Lower/upper Albian & \\
\hline $28-6 ; 49-51$ & 1009 & Lower/upper Albian & \\
\hline $28-3,98-99$ & 1004 & Lower/upper Albian & Plate 6, Figure 6 \\
\hline $27-2,107-109$ & 956 & Lower/upper Albian & \\
\hline $26-6,139-141$ & 914 & Upper Albian & Plate 6, Figure 4 \\
\hline $26-2,139-141$ & 908 & Upper Albian & Plate 7 , Figure 1 \\
\hline $25-4,138-140$ & 864 & Cretaceous & Plate 7 , Figure 4 \\
\hline $24-2,140-141$ & 813 & Cretaceous & Plate 7 , Figure 5 \\
\hline $23-3,102-104$ & 767 & Cretaceous & \\
\hline $23-2,140-143$ & 766 & Cretaceous & Plate 7, Figure 6 \\
\hline $22-1,135-137$ & 717 & Cretaceous & \\
\hline $21-4,67-69$ & 673 & Cretaceous & \\
\hline $20-2,38-40$ & 612 & Cretaceous & Plate 7, Figure 3 \\
\hline $19-4,146-148$ & 579 & Cretaceous & Plate 7 , Figure 2 \\
\hline $14-2,140-142$ & 367 & Cretaceous & \\
\hline $14-2,139-141$ & 367 & Cretaceous & \\
\hline $14-2,125-127$ & 367 & $?$ & \\
\hline $12-1,139-141$ & 299 & Cretaceous & \\
\hline $11-3,139-141$ & 283 & ? & \\
\hline $7-1,139-140$ & 232 & Lower/Middle Eocene & Plate 8 , Figures 1 - 3 \\
\hline $6-2,62-63$ & 205 & Middle Eocene & Plate 8 , Figures 4 - 6 \\
\hline $3-6,104-105$ & 107 & Upper Eocene & \\
\hline
\end{tabular}

resistant to dissolution-are very accurate and testify to the very fine grain size of the matrix.

\section{$43-3,69-70 \mathrm{~cm} ; 43-3,40-41 \mathrm{~cm}$}

These two samples occur in a single silty bed. Detrital particles, well preserved and with sharp angles, are abundant. Analysis 'made using an ORTEC dispersive analysis system coupled with the SEM confirm that they are siliceous. These quartz particles are not encrusted with clay. Clay appears in large amorphous zones or sometimes, as in Sample 43-3, 40-41 cm in well-crystallized form (kaolinite). A few framboids of pyrite occur in this sample.

\section{3-3, 76-77 cm (Plate 2, Figures 1-5)}

Dark grey mud (5Y 3/1) with plant fragments. $\mathrm{CaCO}_{3}$ content $=4 \%$.

Compact sediment, with large amorphous clayey zones (Plate 2, Figures 1, 3); framboids of pyrite, well crystallized, appear in some cracks (Plate 2, Figures 1, 2).

Coccoliths occur here and there in more or less compact groups (Plate 2, Figures 1, 5); frequent placoliths of Watznaueria (Plate 2, Figures 1, 3, 5), some Parhabdolithus sp., Cretarhabdus decussatus ([Manivit] Stradner, 1968) (Plate 2, Figure 4).

The state of preservation of some nannofossils yields indices of the extent of carbonate dissolution: for example, the acuminate end of some elements of the proximal shield of Watznaueria, the internal cycle of the distal shield partially removed (Plate 2, Figure 5). Entirely dissolved coccolith casts also occur.

Despite a high content of clay, nannofossils are not encrusted. Their structures are clean. This observation is related to the large quantity of organic matter in the sample.

\section{$33-3,75-76 \mathrm{~cm}$}

Silty zone rich in plant debris.

\section{3-3, 31-32 cm}

Macroscopically, the sample appears as a dark gray mud with very fine white laminae (of the order of a millimeter). Total carbonate content: $73 \%$. The dark layers and the white laminae are described separately.

The dark layers are shown on Plate 3, figures 1-4. They have large irregular clayey zones (Plate 3, Figures $1,3)$ locally carpeted with dispersed pyrite granules.

Organic remains include plant debris, pollen grains, and numerous well-preserved coccoliths (Plate 3, Figures 1-4). One species, Corollithion rhombicum (Stradner and Adamiker) Bukry, frequently occurs in piles that resemble coccosphere fragments disjointed on the spot (Plate 3, Figures 1-3). This type of fossil preservation has previously been reported in various laminated bituminous limestones (Noël, 1972) and points to calm and confined sedimentation conditions. More will be said about this in the general interpretation of the nannofacies of these series. Further, in the bituminous limestones of Armailles (Noël, 1973, Plate III, Figures 1-3) morphologically very similar coccoliths have been observed. These forms therefore seem well adapted to this type of sedimentation.

Remarks: Among species encountered with the SEM, Corollithion rhombicum (Plate 3, Figure 1) which first appears in the Aptian, Bipodorhabdus biforatus [(Black) Barrier, in press, Plate 3, Figure 3], which is known from upper Aptian stratotype (Gargas, France), and Cretarhabdus decussatus, which appears in the Albian, all point to a lower Albian age for this sample.

The light colored layers are shown on Plate 4, Figures 1-4. Fine white millimeter-sized laminae found in this sample are marked by extremely abundant Nannoconus constituting the bulk of the sediment. These Nannoconus are extremely well preserved. Their elements, of triangular shape (Plate 4, Figure 2) are perfectly distinct and not welded to each other as frequently observed in Lower Cretaceous limestones where recrystallization is well marked. Because of lack of welding between elements, Nannoconus tests can split apart (Plate 4, Figure 3) and individually not be recognized, especially in smear slides. The triangular form of the elements, as well as the angle of the internal point of the element, close to $72^{\circ}$, can be mistaken for elements broken from pentaliths of Braarudosphaera.

The rather short globule-like form of observed Nannoconus and the width of their central cavity point to their attribution to the truitti Brönnimann group and further confirm the Albian age of this sample.

Other coccoliths present include Parhabdolithus asper [(Stradner) Reinhardt, 1967] (Plate 4, Figure 4] 
(perfectly preserved with large intact stem), Bipodorhabdus biforatus, Cyclagelosphaera margereli (Noël, 1965), and Corollithion rhombicum.

The great number of Nannoconus in these white laminae reflects sedimentation in clear water (Noël, 1968).

\section{2-3, 119-121 cm (Plate 5, Figure 1)}

Dark gray silty clay with plant remains, $\mathrm{CaCO}_{3}$ content: $4 \%$. Large amorphous clayey zones (Plate 5, Figure 1). Nannofossils, highly encrusted, are poorly preserved as a rule and include Parhabdolithus asper, and the marginal crown of Cribrosphaera ehrenbergi Arkhangelsky.

Plant debris and pollen were also found.

\section{2-1, 24-25 cm (Plate 5, Figure 2)}

Dark gray, fine, unlaminated mud. Carbonate content: $5.6 \%$. The clay-rich sediment, which has a scaly structure, contains pyrite framboids that are well crystallized and buried in the matrix. Nannofossils, mostly placoliths of Watznaueria, are poorly preserved with obvious dissolution traces.

\section{1-3, 74-76 cm (Plate 5, Figures 3, 4)}

Dark gray silty mud, with plant debris. $\mathrm{CaCO}_{3}=7 \%$. The sediment has a heterogeneous structure, slightly granular in places with small-size clay particles. Pyrite framboids occur in cracks in the sediment.

Nannofossils generally appear in coccolith groups of a single species (probably $P$. asper). These groups are interpreted as remnants of coccospheres disjointed in situ pointing to quiet and confined sedimentation.

\section{1-3, 59-61 cm (Plate 6, Figures 1-3, 5)}

Dark gray (5Y 3/1) coarse silt; carbonate content undetermined. The sediment structure is not very homogeneous. Large amorphous clay zones lie close to piles of clean, distinct nannofossils, with pyrite framboids in cracks.

Coccoliths are diverse: Watznaueria barnesae (Plate 6, Figures 2, 5) and Parhabdolithus asper occur in several clumps (Plate 6, Figure 1). The stem of Parhabdolithus is erratically preserved; it can be totally separate from its base or broken at various levels. In piles of coccolith fragments, free stems are often found. Also in this sample are Cretarhabdus crenulatus (Plate 6, Figure 3), Watznaueria parvidentata [(Deflandre) Bukry], Corollithion rhombicum, Bidiscus cf. rotatorius, Cribrosphaera ehrenbergi, $P$. angustus, and Diazomatolithus lehmani. This association gives a lower/upper Albian age. The presence of Cribrosphaera ehrenbergi places this sample in the Prediscosphaera cretacea Zone of Thierstein (1971).

Watznaueria barnesae placoliths are unevenly preserved. They can be found in groups of coccosphere fragments (Plate 6, Figure 2) and are highly dissolved in places.

\section{$30-2,57-59 \mathrm{~cm}$}

Dark gray sandstone, with plant fragments; $\mathrm{CaCO}_{3}$ $=2 \%$.

\section{9-5, 129-131 cm}

Dark gray silty mud. $\mathrm{CaCO}_{3}=2 \%$.

$29-4,94 \mathrm{~cm}$

Black bituminous shale. $\mathrm{CaCO}_{3}=2.8 \%$.

28-6, 49-50 cm

Very black bituminous shale $(2,5 \mathrm{Y}, 2 \%)$. $\mathrm{CaCO}_{3}=4.5 \%$.

28-3, 98-99 cm

Dark gray mud $(5 \mathrm{Y} 4 / 1) . \mathrm{CaCO}_{3}=2.4 \%$.

$27.2,107-109 \mathrm{~cm}$

Gray-green mud (5Y 4/1). $\mathrm{CaCO}_{3}=2.8 \%$.

These six samples have roughly similar characteristics. They are rich in amorphous clay and pyrite framboids in cracks (Samples 29-5, 129-131 cm; 29-4, 92-94 cm; 28-3, 98-99 cm; 27-2, 107-109 cm). Wellcrystallized clays are often seen (Plate 10, Figure 6). No nannofossils occur but some impressions can be seen in sample 28-6, 43-51 cm.

\section{6-6, 139-41 cm (Plate 6, Figure 4)}

Chocolate-brown mud ( 5 YR 4/2), carbonate content: $29 \%$. This clay-rich sediment is irregularly compacted, with holes in places. Nannofossils are not rare but are highly encrusted with clay and sometimes damaged. Stephanolithion laffittei Noël, 1958 (Plate 6, Figure 5) are frequent; Podorhabdus orbiculofenestrus [(Gartner) Thierstein, 1971) and Watznaueria barnesae, Biscutum sp., Zygolithus sp. also occur.

\section{6-2, 139-141 cm (Plate 7, Figure 1)}

Chocolate-brown mud ( $\mathrm{Y}$ YR $4 / 2$ ), $\mathrm{CaCO}_{3}=4 \%$. This very fine clayey sediment, contains tiny clay particles with upturned edges and displays honeycomb structure (Plate 7, Figure 1). Nannofossils found on smear slides were not seen with the SEM.

According to shipboard macroscopic observations the last three samples should be placed in Unit 6. But the structure of the sediments as also their nannofossil content is much more similar to those of Unit 7. Our study being based on nannofacies observations, it has seemed more logical to us to respect the difference in the sediment breakdown, and include these samples in the lower unit.

\section{Sedimentological Interpretation of Nannofacies for Cores $\mathbf{4 8 - 2 6}$}

Cores 48 to 26 represent a homogeneous set with the following characteristics:

1) A high percentage of often fine clay material distributed in amorphous zones of various size and sometimes well-crystallized clay minerals;

2) A high content of organic matter occurring as debris of all sorts or in a diffuse manner probably impregnating the clay minerals. This bituminous clayey mix constitutes the very fine and plastic sediment matrix in which excellent impressions have been left by coccoliths. This matrix has reacted little, with 
nannofossils encrusting them only slightly. Their structure is consequently clearly visible. This is not so in the solely clay sediments lacking organic matter. It is as if bituminous-clayish matrix cannot adhere to the coccolith surfaces possibly because they are coated with an organic film.

Pyrite is almost always present, either carpeting the sediment, or more often as distinct framboids made of octahedral crystals. The origin and condition of formation of these framboids have been ascribed to several hypotheses ranging from the action of colonies of thiobacteria (Fabricius, 1961) to simple inorganic crystallization (Rust, 1935; Bastin, 1950). For Honjo et al. (1965), bacteria play at least an indirect role, through the creation of anaerobic conditions and the liberation of sulfur. Combaz (1970) also supported a direct bacterian origin. Sweeney and Kaplan (1973) have provided interesting data on the conditions of formation of framboidal pyrite. From their studies both in the laboratory and in the field (California Basin, Red Sea) under certain conditions, in particular in the presence of oxygen and in either anhydrous (vacuum) or hydrous environments, framboids can precipitate directly. The presence of framboids in the biologically active sediments of California basins and some basins of the Red Sea (where, however, deeps with brines do not contain any) has led them to suggest that $p \mathrm{H}$ is influential in the mechanism of formation. If the $p \mathrm{H}$ is less than 8 , precipitation from metastable iron sulfide solutions is inhibited. Under these conditions, pyrite can be formed but not of framboidal texture. This implies a high $p \mathrm{H}$, or alkaline conditions of framboidal pyrite formation at Site 361 .

This high $p \mathrm{H}$ role is difficult to explain, considering that calcareous nannofossils sometimes appear as impressions with complete dissolution of the original nannofossils. This dissolution has taken place in the sediment itself since for the impression to exist, the fossils have to be buried and a minimum amount of compaction must have occurred. The dissolution indices are thus related to diagenetic processes and not at all to the depth of the sediment. Within the sediments, such dissolution can occur even in shallow water. But one would expect the dissolution to be a result of acidic rather than alkaline conditions.

Nannofossils occur in most samples studied. Only sandy zones are azoic. Nannoflora are diverse pointing to fairly nutrient-rich conditions. Surface waters of the Cape Basin, no doubt of marine origin, allowed these organisms to develop. The frequent piles of coccoliths of a single species are interpreted as remnants of in situ dislocated coccospheres.

Several authors, Hattin (1975), Honjo (1975), Roth et al. (1975) have stressed the role played by copepods in the formation of such aggregates. These authors have demonstrated that herbivorous copepods, eating phytoplankton, add their fecal pellets to the carbonateoceanic sediments. Honjo and Roth et al. emphasize that the time of descent of coccoliths through the water column is accelerated in this manner, and that particles can reach the sea floor without too much damage to their structure. Therefore great care should be exercized when attempting to deduce the depth of the basin from the state of nannofossil preservation.

In the present case, these arguments together with the presence of pyrite framboids and organic material, allow us to interpret the single-species coccoliths aggregates as coccosphere remnants dislocated in situ just as they were being deposited; they therefore imply a calm and stagnating depositional environment. In Core 33 , very fine white millimeter-sized laminae are formed almost exclusively of Nannoconus, while adjacent layers are made exclusively of coccoliths. Similar occurrences were described by Noël (1967) in alternating limestone and marl sequences of Barremian age from the Vocontian through.

At Site 361, this almost exclusive abundance of Nannoconus in some layers can once more be interpreted as evidence for sedimentation in episodically very limpid waters.

In summary, nannofossil examination shows that in the Aptian/middle-upper Albian, the Cape Basin at Site 361 contained marine waters, in which silts and sands loaded with plant debris and pollen derived from the continent were deposited. The euphotic surficial layer sustained coccolithophorids. At times, when waters were more limpid, Nannoconus alone lived. The nannofacies also support the evidence of the abundant organic material and pyrite that the basin waters were stratified with a confined, stagnating, and probably anaerobic bottom layer.

The depth of deposition cannot be deduced from nannofacies that have been studied.

\section{Undifferentiated Cretaceous: Cores $\mathbf{2 5}$ to $\mathbf{1 2}$}

Cores 25-12 consist of 540 meters of interbedded red or green shales and grayish-green siltstones. The carbonate content is always less than $5 \%$.

\section{Sample Descriptions}

Twelve samples have been studied using the SEM.

25-4, 138-140 cm (Plate 7, Figure 4)

Olive-gray extremely fine mud (5Y $5 / 2)$ with $3 \%$ $\mathrm{CaCO}_{3}$.

24-2, 140-141 cm (Plate 7, Figure 5)

Dark (5Y 3/1) to light (5Y 4/1) gray laminated very fine mud with $\mathrm{CaCO}_{3}=3 \%$.

These two samples display a characteristic heterogeneous, granular structure, with detrital particles (clay aggregates?) poorly sorted and irregular. No nannofossils.

23-2, 102-104 cm

Dark olive-gray (5Y 3/2) mud with $\mathrm{CaCO}_{3}=3.1 \%$. Various sized crystalline particles in a clayey matrix of a much larger proportion than samples of Core 24 .

23-2, 140-143 cm (Plate 7, Figure 6)

Dark gray (5Y 3/1) very fine mud with $2.7 \% \mathrm{CaCO}_{3}$. Increase of clay content still greater than preceding sample. Scaly structure, with irregular amorphous 
zones, upturned borders. Some well-crystallized pyrite framboids (Plate 7, Figure 6).

This is the only sample with pyrite.

\section{2-1, 135-137 cm}

Reddish brown (5Y 3/2) very fine mud with $4 \%$ $\mathrm{CaCO}_{3}$. Very clay-rich sediment, highly compacted with a homogeneous and scaly structure.

\section{1-4, 67-69 cm}

Gray (5Y 4/1) mud with $3 \% \mathrm{CaCO}_{3}$. Crystalline particles, mostly quartz, with sharp angles of various size poorly embedded in a clay matrix. Nannofacies highly comparable to Sample 24-2, 140-141 cm.

20-2, 38-40 cm (Plate 7, Figure 3)

Dark gray (5Y 3/1) mud with $3 \% \mathrm{CaCO}_{3}$.

19-4, 146-148 cm (Plate 7, Figure 2)

Reddish brown mud with $3.5 \% \mathrm{CaCO}_{3}$. Nannofacies of the last two samples display a scaly clay structure; the clays are in general small, irregular in shape with upturned borders.

\section{4-2, 140-142 cm}

Olive-gray micaceous clayey mud, with $3 \% \mathrm{CaCO}_{3}$.

\section{$14-2,139-141 \mathrm{~cm}$}

Dark olive-gray silty mud, with $4 \% \mathrm{CaCO}_{3}$.

\section{4-2, 125-127 cm}

Sandy mud. Samples show predominantly aggregates and poorly sorted crystalline particles with sharp borders.

\section{Sedimentological Interpretation of Nannofacies for Cores 25 to 12}

The lack of nannofossils in the samples and the dominant amorphous clay fraction make it difficult to interpret the nannofacies.

But, in general, conditions leading to clay-particle aggregates apparently prevailed. This implies some agitation as proven by the presence of sedimentary structures (Chapter 2, this volume).

Quieter periods for Cores 23-22 and 20-19 gave finer clay deposits, homogeneous, and well compacted.

Sampling, although not exhaustive, was done according to facies changes and is thought to be representative of the section.

From nannofacies alone, it cannot be ascertained whether the absence of nannofossils is primary or whether it results from a complete dissolution of carbonate.

\section{Cores 12 and 11: Paleocene (?)}

The upper limit of this interval cannot be ascertained because the sample spacing from Core 11 to Core 7 was too large. However, lithological descriptions of cores show that the pelagic clay facies continues into Core 10 and in Sections 6, 5, 4, and base of 3 in Core 9.

\section{Sample Descriptions}

12-1, 139-141 cm; 11-3, 139-141 cm

Fine clayey sediment, irregularly compacted with small size clay particles, with upturned borders yielding a scaly structure. No nannofossils.

\section{Sedimentological Interpretation of \\ Nannofacies of Cores $\mathbf{1 2}$ and $\mathbf{1 1}$}

As with the previous interval, the absence of organisms and the high content of amorphous clay material make the interpretation difficult. One can reasonably assume quiet sedimentation conditions.

Eocene, Cores 7 to 3

\section{Sample Descriptions}

7-1, 139-140 cm (Plate 8, Figures 1-3);

6-2, 62-63 cm (Plate 8, Figures 4-6)

Bluish gray marly mud, with $55 \% \mathrm{CaCO}_{3}$.

Nannofacies for the two levels are similar. The clay fraction is made of small irregular zones with uplifted borders yielding a scaly structure. Calcareous nannofossils are not rare, and moderately well preserved. Some placoliths have completely lost their central area (Plate 8, Figure 4), They are heavily encrusted with clay, making their identification difficult.

The following species have been recognized: Neococcolithes dubius (Plate 8, Figure 5), Chiasmolithus grandis [(Bramlette and Riedel) Radomski, 1968] (Plate 8, Figure 6), and Chiasmolithus solitus (Bramlette et Sullivan) Gartner, 1970.

3-6, 104-105 cm

Light gray silty mud. Heterogeneous structure with detrital particles with round borders. No nannofossils.

\section{SITE 360}

Water depth at the drill site was 2949 meters, and 839.5 meters of lower Pliocene to middle Eocene sediments were recovered. Sedimentation was relatively homogeneous, predominantly calcareous, but with a greater terrigenous influx during the Eocene.

Facies analysis reveals two main sedimentation periods-one from the middle Eocene to lower Oligocene-the other from the lower Oligocene to lower Pliocene.

This division rather than the lithologic subdivisions of Chapter 2 will be used for nannofacies study because the sampling interval was not closely spaced. Samples studied by the SEM were selected on the basis of the fragmentation of foraminifers as observed in smear slides. Since this fragmentation was due to dissolution, the state of preservation of foraminifers was used as a guide to the likely state of preservation of the nannofossils (See Table 2).

\section{Middle Eocene-Lower Oligocene}

Cores 50-33 represent a total of 250 meters of marly limestone which are relatively indurated, greenish gray 
TABLE 2

Site 360

\begin{tabular}{|c|c|c|c|}
\hline $\begin{array}{c}\text { Sample } \\
\text { (Interval in } \mathrm{cm} \text { ) }\end{array}$ & $\begin{array}{l}\text { Approximate } \\
\text { Position } \\
\text { in Hole } \\
\text { (m) }\end{array}$ & Age & Illustrations \\
\hline $50-1,139-141$ & 831 & Middle Eocene & Plate 9, Figures 1, 2 \\
\hline $46-4,139-141$ & 760 & Middle Eocene & Plate 9, Figure 3 \\
\hline $44-2,139-141$ & 719 & Middle Eocene & $\begin{array}{l}\text { Plate 9, Figures 4-5 } \\
\text { Plate 2, Figures 4-5 }\end{array}$ \\
\hline $34-1,139-141$ & 546 & Lower Oligocene & Plate 10 , Figures $1-3$ \\
\hline $33-5,139-141$ & 532 & Lower Oligocene & Plate 11, Figures $4-5$ \\
\hline $19-2,139-141$ & 263 & Middle Miocene & Plate 11, Figures 1-3 \\
\hline $12-5,139-141$ & 191 & Upper Miocene & Plate 12, Figure 5 \\
\hline $10-3,139-141$ & 169 & Upper Miocene & Plate 12, Figure 6 \\
\hline $8-3,138-141$ & 150 & Upper Miocene & Plate 12, Figures 2- 4 \\
\hline $1-1,139-141$ & 81 & Lower Pliocene & Plate 12, Figures 1-3 \\
\hline
\end{tabular}

in color, and little disturbed by bioturbation. The mean $\mathrm{CaCO}_{3}$ content is $40 \%$. The clay fraction is large, but quartz in low concentrations is erratically distributed throughout these cores.

\section{Sample Descriptions}

50-1, 139-141 cm (Plate 9, Figures 1, 2);

46-4, 139-141 cm (Plate 9, Figure 3)

Middle Eocene: $46 \% \mathrm{CaCO}_{3}$ for the first sample, $51 \%$ $\mathrm{CaCO}_{3}$ for the second sample.

These two samples have the same nannofacies and are dominated by clays in lamellae of various thicknesses. The clays have irregular borders often upturned. The sediment is irregularly compacted.

Calcareous nannofossils, mainly placoliths, are always present but never form large aggregates. They are deeply buried in the clay matrix, thus making their determination difficult. Their state of preservation is good.

The similarity of nannofacies with previously described samples from Site 361 (Samples 6-1, 139-140 $\mathrm{cm}$, and $6-2,62-63 \mathrm{~cm}$, Plate 8, Figures 1-6) is remarkable. They correspond to the overlap zone between Sites 360 and 361 . The similarity shows that this type of sediment was not localized in one place but was generally distributed on the southern African continental margin.

\section{4-2, 139-141 cm (Plate 9, Figures 4, 5; Plate 10, Figures 4, 5 )}

Middle Eocene, $39 \% \mathrm{CaCO}_{3}$.

Despite a lower carbonate content, nannofossils are more abundant than in the two previous samples. They form clumps of several fossils of different species (Plate 9, Figure 5; Plate 10, Figures 4, 5).

The coccoliths are of large size, locally grouped in coccospheres, and do not show any dissolution traces. Clay encrustation is minor and the fossils are easily separated from the matrix. Foraminifer chambers found in the sediment show little recrystallization. Salt encrustations are frequent (Plate 9, Figure 4).

34-1, 139-141 cm (Plate 10, Figures 1-3); 33-5, 139-141 cm (Plate 11, Figures 4, 5)

Lower Oligocene, $76 \% \mathrm{CaCO}_{3}$ for the first sample, $68 \% \mathrm{CaCO}_{3}$ for the second. The nannofacies is characterized by abundant generally well-preserved nannofossils. Only a few placoliths have lost their central area (Plate 10, Figure 3). Whole coccospheres are not rare (Plate 10, Figure 1). In Section 33-5, coccoliths are found in all positions, sometimes in clumps (Plate 11, Figure 4).

Among the encountered species is Coccolithus eopelagicus (Bramlette and Riedel) Bramlette and Sullivan, 1961.

\section{Interpretation of Nannofacies}

First, although fragmentation is high for foraminifers (Melguen, this volume), nannofossils are on the contrary well preserved and not affected by dissolution. Most species are large placoliths, the least fragile.

The clay fraction is clearly visible in the middle Eocene nannofacies. But during the lower Oligocene, the carbonate fraction becomes dominant; clays are minor or absent.

\section{Lower Oligocene-Lower Pliocene Interval: Cores 32 to 1}

Four hundred and thirty-seven meters of light to medium gray, very homogeneous marly chalks with no visible structures.

$\mathrm{CaCO}_{3}$ is high $(60-80 \%)$ and of organic origin (nannofossils and foraminifers).

\section{Sample Descriptions}

19-2, 139-141 cm (Plate 11, Figures 1-3)

Middle Miocene. Sediments are characterized by abundant calcareous nannofossils, mostly placoliths, more or less well preserved. Numerous fragments of coccoliths are mixed with very fine individual clay particles and clays which encrust nannofossil structures.

\section{2-5, 139-141 cm (Plate 12, Figure 5) Upper Miocene}

10-3, 139-141 cm (Plate 12, Figure 6) U Upper Miocene

8-3, 139-141 cm (Plate 12, Figure 2-4) Upper Miocene

1-1, 139-141 cm (Plate 12, Figures 1-3) Lower Miocene

Nannofacies characteristics are similar to those of the preceding sample. The abundance of nannofossils is the same. They are usually grouped in clumps (Plate 12, Figure 1). Dissolution traces are evident (Plate 12, Figure 6) despite the presence of well-preserved coccospheres at some levels (Plate 12, Figures 2-4).

The clay fraction is very fine and encrusts the structures. It is also present as very small particles.

\section{Interpretation of Nannofacies}

It is difficult to give a comprehensive interpretation of this interval, because of large gaps between samples. However, the similarity of the nannofacies encountered indicates that the sequence is homogeneous and reflect sedimentation at fairly great depths in contrast to Cores $50-33$. This is in perfect agreement with results obtained from planktonic foraminifer fragmentation data. 
It is also important to recall that the limits between the two intervals studied have not been established from nannofacies characteristics. Since no sample between Cores 33 and 19 was examined, it was better to characterize the two intervals middle Eocene to lower Oligocene (Cores 50-33) and upper Oligocene to lower Pliocene (Cores 33-1) using sedimentological data obtained by classical analysis (grain-size, smear slides, etc.).

\section{WALVIS RIDGE (HOLES 362, 362A, AND SITE 363)}

Holes 362 and $362 \mathrm{~A}$ were located on the Abutment Plateau on the northern border of the Cape Basin of the Walvis Ridge. They penetrated a continuous series from Pleistocene to lower Eocene.

From a lithological point of view, four main units can be outlined:

1) a marly unit with more calcareous zones of Eocene age (Hole 362A, Cores 12-6).

2) a unit with chalk levels, of Oligocene age (Hole $362 \mathrm{~A}$, Cores 5-2).

3) a marly unit, of lower to upper Miocene age (Site 362, Cores 44-27).

4) a siliceous-marly unit of upper Miocene age to Pleistocene (Site 362, Cores 26-1).

Samples from each of these units (Tables 3 and 4) have been studied with the SEM.

\section{Unit 1}

This unit is made of 160 meters of marly limestones with some more calcareous zones. $\mathrm{CaCO}_{3}$ content is high.

\begin{tabular}{|c|c|c|c|}
\hline & & $\begin{array}{l}\text { TABLE } 3 \\
\text { Hole } 362 \text { A }\end{array}$ & \\
\hline $\begin{array}{c}\text { Sample } \\
\text { (Interval in } \mathrm{cm} \text { ) }\end{array}$ & $\begin{array}{l}\text { Approximate } \\
\text { Position } \\
\text { in Hole } \\
(\mathrm{m})\end{array}$ & Age & Illustrations \\
\hline $9-1,122-124$ & 997 & Middle Eocene & Plate 13, Figures 4-6 \\
\hline $8-4,31-33$ & 972 & Middle Eocene & Plate 14, Figures 1, 2 \\
\hline $8-2,77-79$ & 969 & Middle Eocene & \\
\hline $5-5,114-116$ & 917 & Oligocene & Plate 13, Figure 1 \\
\hline $5-3,60-62$ & 914 & Oligocene & Plate 13 , Figure 2 \\
\hline $5-2,54-56$ & 912 & Oligocene & Plate 14 , Figures $3-4$ \\
\hline $5-1,86-88$ & 911 & Oligocene & Plate 13 , Figure 3 \\
\hline $4-6,81-83$ & 880 & Middle Oligocene & Plate 15 , Figures 1,2 \\
\hline $4-5,69-71$ & 879 & Middle Oligocene & Plate 15, Figure 3 \\
\hline $4-4,146-148$ & 878 & Middle Oligocene & Plate 15, Figure 4 \\
\hline $4-3,53-55$ & 876 & Middle Oligocene & Plate 16, Figures 1 - 3 \\
\hline $3-6,149-151$ & 843 & Middle Oligocene & Plate 17, Figure 1 \\
\hline
\end{tabular}

TABLE 4

Hole 362

\begin{tabular}{|c|c|c|c|}
\hline $\begin{array}{c}\text { Sample } \\
\text { (Interval in } \mathrm{cm} \text { ) }\end{array}$ & $\begin{array}{c}\text { Approximate } \\
\text { Position } \\
\text { in Hole } \\
(\mathrm{m})\end{array}$ & Age & Illustrations \\
\hline $41-6,135-141$ & 738 & $\begin{array}{l}\text { Lower Miocene/ } \\
\text { upper Oligocene }\end{array}$ & Plate 17, Figures 2 - 4 \\
\hline $35-1,139-141$ & 579 & $\begin{array}{l}\text { Lower/middle } \\
\text { Miocene }\end{array}$ & Plate 17, Figure 5 \\
\hline $27-5,91-93$ & 413 & Miocene & Plate 17 , Figure 5 \\
\hline $26-1,139-141$ & 389 & Upper Miocene & Plate 18, Figures $1-4$ \\
\hline $21-1,139-141$ & 294 & Upper Miocene & Plate 18 , Figures $5-6$ \\
\hline
\end{tabular}

\section{Sample Description}

362A-9-1, 122-124 cm- Middle Eocene (Plate 13, Figures 4-6)

Very fine limestone, quite homogeneous, highly lithified, of light gray color $(5 \mathrm{Y} 8 / 1)$ with a $\mathrm{CaCO}_{3}$ content of $89 \%$.

The nannofacies is characterized by abundant large calcite crystals (Plate 13, Figures 4-6) and fibrous spherules probably of cristobalite (Plate 13, Figure 6). Nannofossils are frequent and well preserved.

Identified species are: Cyclococcolithus formosus Kamptner, 1963, Toweius callosus Perch Nielsen, 1971 (Plate 13, Figure 6), and Discoaster gr. tani Bramlette and Riedel, 1954.

362A-8-4, 31-33 cm (Plate 14, Figures 1, 2); 8-2, 77-79 cm

Greenish gray-light green (5GY 6/4) calcareous mud, slightly marly, highly indurated, with $\mathrm{CaCO}_{3}=75 \%$. Nannofossils are imbedded in an amorphous clay matrix.

\section{Interpretation of Nannofacies}

The presence of cristobalite spherules in the limestones $(9-1,122-144 \mathrm{~cm})$ constituting a sort of cement between organic elements is noteworthy. So are the large calcite crystals which probably result from secondary recrystallization, either diagenetic, or syngenetic. Similar limestones have been found on DSDP Leg 3 (Wise and Hsü, 1971).

\section{Unit 2 - Oligocene}

Cores 5-2 of Hole 362A, represent 120 meters of greenish to brownish gray mud, with white calcareous beds, usually fluid oozes, especially in the zone studied.

Cores 4 and 5 are alternating green-gray to brown marly chalks and white fine laminae of limestone.

\section{Sample Description}

Several levels of Cores 4 and 5 have been studied with the SEM in order to see how this alternating lithology is represented by the nannofacies.

362A-5-5, 114-116 cm (Plate 13, Figure 1)

362A-5-3, 60-62 cm (Plate 13, Figure 2)

Light gray very fine mud, indurated, with $\mathrm{CaCO}_{3}=87 \%$. Perfectly preserved coccoliths (Plate 13 , Figure 1) are found, plus highly recrystallized placoliths mixed with large calcite crystals. Thus the structure of the sediment appears heterogeneous, with large gaps between elements.

362A-5-2, 54-56 cm (Plate 14, Figures 3, 4)

Dark gray (5Y 4/1) fine marly mud, with $\mathrm{CaCO}_{3}=49 \%$. The nannofacies is characterized by a more compact structure than the above samples. Between coccoliths, mostly resistant placoliths, occur amorphous clay particles (Plate 14, Figure 3). The sediment is less porous than at the interval level of the calcareous beds described above. 
362A-5-1, 86-88 cm (Plate 13, Figure 3)

Light gray ( 5 Y $7 / 1)$ very fine calcareous mud, highly indurated, $\mathrm{CaCO}_{3} 87 \%$.

The nannofacies is comparable to Samples 5-5, 114$116 \mathrm{~cm}$ and 5-3, 60-62 cm. Large placoliths, fragments of Braarudosphaera, and some Thoracosphaera sp. occur, mixed with crystals of secondary calcite.

362A-4-6, 81-83 cm (Plate 15, Figures 1, 2)

This is a highly indurated calcareous zone ( $92 \%$ $\mathrm{CaCO}_{3}$ ), with nannofacies similar to the lithologically analogous zones of Core 5.

362A-4-5, 69-71 cm (Plate 15, Figure 3)

This sample is very rich in foraminifers in a poor state of preservation. Numerous test fragments occur which are little recrystallized in the sediment. Nannofossils are abundant.

362A-4-4, 146-148 cm (Plate 15, Figure 4)

Medium gray, very fine mud with numerous fragments of foraminifer tests, and clay-encrusted nannofossils. The clays appear as amorphous zones.

362A-4-3, 53-55 cm (Plate 16, Figures 1-3)

Light olive-gray (5Y 5/2) fine mud, with $54 \% \mathrm{CaCO}_{3}$. A very particular type of nannofossil sedimentation is observed; at places, there is a layer of a single coccolith species, Reticulofenestra bisecta, laid side by side and curiously all oriented their proximal side up. Such an arrangement implies probably very calm conditions especially close to the bottom.

362A-3-6, 149-151 cm (Plate 17, Figure 1)

A relatively compacted sediment, not very porous with placoliths deeply buried in the clay matrix.

\section{Interpretation of Nannofacies}

The lower and middle Oligocene is characterized by alternating indurated carbonates and marly muds. The layers are of the order of $10 \mathrm{~cm}$ thick.

Poorly compacted carbonate beds show large gaps between organisms (coccoliths, foraminifer fragments) and crystals of secondary calcite. Cementation is also due to cristobalite spherules. In some intervals smear slides show the quasi-exclusive presence of Braarudosphaera, whole or fragmented. SEM-studied samples did not permit this observation.

Marly beds are more compact and contain wellpreserved coccoliths.

\section{Unit 3}

Lower Miocene to upper Miocene, Site 362, Cores 44 to 27. Four-hundred meters of green-gray marly chalk, with $30 \%$ to $75 \% \mathrm{CaCO}_{3}$.

\section{Sample Description}

362-41-6, 139-141 cm (Plate 17, Figure 4): $48 \% \mathrm{CaCO}_{3}$

362-35-1, 139-141 cm (Plate 17, Figure 5): $52 \% \mathrm{CaCO}_{3}$
362-27-5, 91-93 cm

The highly clayey sediments show clay-encrusted nannofossils with poorly visible structures. Fragments are wedged between amorphous clay zones. The nannofacies is similar to that in marly layers of the previous unit.

\section{Unit 4}

Upper Miocene to Pleistocene, Site 362, Cores 26-1; 400 meters of marly mud with more or less abundant siliceous microfossils.

\section{Sample Description}

362-26-1, 139-141 cm (Plate 18, Figures 1-4)

$56 \% \mathrm{CaCO}_{3}$. This rather compacted sediment (Plate 18 , Figure 3) contains abundant diverse nannoflora in a good state of preservation. Partially dissolved radiolaria (Plate 18, Figure 1) and diatom frustules can also be found.

362-21-1, 139-141 cm (Plate 18, Figures 5, 6)

$80 \% \mathrm{CaCO}_{3}$. Organic components are similar to Cores 26-1, with radiolaria, which are more or less dissolved, and nannofossils that appear more damaged (Plate 18, Figure 6).

Site 363 was located on the northern flank of Frio Ridge part of the Walvis Ridge. Sediments from Miocene to Lower Cretaceous were recovered. At this site, our SEM study was devoted exclusively to the Braarudosphaera chalk found at the lower Oligocene (Table 5).

Macroscopically, the sediment appears as a rather fluid ooze, interbedded with nannofossil chalks, in Core 4, Section 2; Core 5, Sections 1-3, 5; Core 6, Sections 3, 4; and Core 7, Section 1 and CC.

The thickness of the Braarudosphaera layers varies from 10 to $80 \mathrm{~cm}$.

\section{Sample Description}

7-1, CC: (Plate 19, Figures 2, 3); 7-1, 139-141 cm (Plate 19, Figure 1)

The chalk appears as an accumulation of whole pentaliths, abundant in places, and numerous fragments, which are disaggregated elements of isolated pentaliths, and broken fragments of these. Some placoliths and massive discoasters (Plate 19, Figure 2) occur, both with recrystallization traces. No cement other than fragments of Braarudosphaera can be seen.

\section{BRAARUDOSPHAERA CHALK PROBLEM IN THE SOUTHERN ATLANTIC OCEAN}

This problem has been mentioned by several authors, notably Berger (1972), Wise and Kelts (1972), and

TABLE 5

Site 363

\begin{tabular}{lll}
\hline $\begin{array}{c}\text { Sample } \\
\text { (Interval in cm) }\end{array}$ & \multicolumn{1}{c}{ Age } & \multicolumn{1}{c}{ Illustrations } \\
\hline $7-1, \mathrm{CC}$ & Lower Oligocene & $\begin{array}{l}\text { Plate 19, Figures 2, 3 } \\
\text { Plate 19, Figure 1 }\end{array}$ \\
\hline$-1,139-141$ & Lower & \\
\hline
\end{tabular}


Melguen et al. (1975). Similar chalks of the same age have been reported from DSDP Leg 3 (Sites 14, 17, 19, 20,22 ) and Leg 39 (Site 359). During Leg 40, they were cored at Sites 362 and 363.

From present Braarudosphaera ecological needs, we know that they are neritic forms that live in coastal ponds (Lefort, 1973) adapted to a lower than normal salinity (Bukry, 1974). These two conditions seem contradictory with the presence of Braarudosphaera chalk during the Oligocene in central portions of the South Atlantic.

Several hypotheses have been proposed to account for this apparent contradiction. Sites where they have been found are close to (1) the Walvis Ridge (40-362, $363)$, (2) the Rio Grande Rise (3-14-19-20-22; 39-359), and (3) the Mid-Atlantic Ridge (3-17), all elevated features. These chalks, therefore, may have been deposited on ridges at shallow depth and been carried away by currents. However, their deposition was periodic as witnessed by the lithology of these sediments. Furthermore, if such Braarudosphaera chalks were shallow water neritic deposits, evidence for carbonate build-up or benthic organisms is lacking. The layers are also almost entirely of the single species. Finally, current transport away from ridges would have altered the purity of these chalks.

A second hypothesis involves sporadic and repeated appearance of particular environmental conditions. This hypothesis seems more satisfactory even if the cause and nature of the environmental changes are not known. However, units in which Braarudosphaera chalk has been found to extend laterally over a band going roughly from $20^{\circ}$ to $30^{\circ}$ south. This is an elongated and narrow belt in which, at least periodically, special environmental conditions may have existed. These may have been related to as yet poorly established oceanic circulation patterns unique to that period.

\section{ANGOLA BASIN}

Drill Site 364 penetrated Quaternary to lower Cretaceous sediments

Only one sample of Aptian age has been studied by the SEM (Table 6).

\section{4-42-2, 9-10 cm (Plate 19, Figures 4-6)}

Black shales interbedded in slightly dolomitic marly limestones.

The nannofacies is characterized by a very fine bituminous clay matrix in which more or less dissolved nannofossils casts are found (Plate 19, Figure 6). Well crystallized pyrite framboids are present. The nannoflora is well diversified and relatively well preserved.

TABLE 6

Site 364

\begin{tabular}{ccc} 
& \multicolumn{2}{c}{ TABLE 6 } \\
Site 364 & \\
\hline $\begin{array}{c}\text { Sample } \\
\text { (Interval in cm) }\end{array}$ & Age & Illustrations \\
\hline $42-2,9-10$ & Upper Aptian & Plate 19, Figures 4-6 \\
\hline
\end{tabular}

This sample looks very much like those of the Cape Basin at the same period.

\section{GENERAL CONCLUSIONS}

The present work is a detailed scanning electron microscope survey of 66 samples from Leg 40. Each interval studied has been carefully related to the sedimentary sequence at each site. For each sample, all major sedimentological characteristics have been outlined. The SEM analysis has thus carried the study of these sediments a step further.

The Cape Basin sediments have been studied in greater detail, especially the Cretaceous units containing bituminous shales of Aptian-Albian age, and the younger undifferentiated Cretaceous red or green clays interbedded with siltstones. In these shales a nannofacies with a major fine clay fraction, abundant pyrite framboids, and variably preserved nannoflora (probably related to the environment $p \mathrm{H}$ ) has been described. The younger undifferentiated Cretaceous units were found to be azoic with large and abundant clay aggregates. Despite sparser sampling for Tertiary units, their nannofacies have been studied and the importance of calcareous nannoflora shown.

From Sites 362 and 363 near Walvis Ridge Braarudosphaera oozes identical to those found at several other sites in the South Atlantic between $20^{\circ}$ and $30^{\circ} \mathrm{S}$ were studied. Other samples from Sites 362 and 363 were studied. The main facies types observed macroscopically along the cores were described.

Study of the Angola Basin has been limited to the comparison of a single sample from Site 364. Its nannofacies is an upper Aptian bituminous shale similar to Aptian sediments of Site 361 in the Cape Basin.

\section{ACKNOWLEDGMENTS}

The authors wish to thank Professor Georges Busson (Geology, National Museum of Natural History, Paris) for valuable discussions and for reviewing and suggesting improvements in the manuscript.

Thanks are also due to Dr. Vincent Renard (C. O. B., Brest) for his help in the English translation of this paper.

Dr. Jim Natland kindly reviewed the manuscript and improved the English version.

SEM pictures taken by D. N. were printed by Miss $M$. Destarac at the Geological Laboratory (Museum, Paris).

\section{REFERENCES}

Barrier, J., in press. Nannofossiles calcaires du Gargasien stratotypique: Bull., M.N.H.N.

Berger, W. H., 1972. Deep-sea carbonates: dissolution facies and age-depth constancy. Nature: 236, p. 392-395.

Bernier, P., Busson, G., Enay, R., and Noël, D., 1972. Les calcaires bitumineux d'Armailles, formation laminée du Kimmeridgien de la région de Belley (Ain), et leurs conditions de dépôt. C. R. Acad. Sci. Paris, v. 274, p. $2925-2928$.

Bukry, D., 1974. Coccoliths as paleosalinity indicators, evidence from Black sea. In The Black Sea - geology, chemistry and biology: A. A. P. G. Mem. 20, p. 353-363.

Bukry, D., and Percival, S. F., 1971. New tertiary calcareous nannofossils: Tulane Stud. Geol. Paleontol., v. 8, p. 123146. 
Busson, G. and Noël, D., 1972. Sur la constitution et la genèse de divers sédiments finement feuilletés ("Laminites") à alternances de calcaire et de matière organique ou argileuse: C. R. Acad. Sci. Paris, v. 274, p. $3172-3175$.

Combaz, A., 1970. Microsphérules muriformes dans les roches-mères du pétrole: hypothèse sur leur origine: $\mathrm{C}$. $\mathrm{R}$. Acad. Sci. Paris, p. 2240-2243.

Hattin, D. E., 1975. Petrology and of origin fecal pellets in upper cretaceous strata of Kansas and Saskatchewan: J. Sediment. Petrol., v. 45, p. 686-696.

Honjo, S., 1975. Dissolution of suspended coccoliths in the deep-sea water column and sedimentation of coccolith ooze. In Sliter, W. W., Bé, A. W. H., and Berger, W. H. (Eds.), Dissolution of deep-sea carbonates: Cushman Found. Foram. Res., Spec. Pub. 13, p. 114-128.

Honjo, S., Fischer, A. G., and Garrison, R., 1965. Geopetal pyrite in fine grained limestones: J. Sediment. Petrol., v. 35 , p. $480-488$.

Lefort, F., 1973. Etude de quelques Coccolithophoracés marins appartenant aux genres Hymenomonas, Ochrosphaera, Braarudosphaera: Thèse third cycle Université Rennes.

Melguen, M., et al., 1975. Facies evolution and carbonate dissolution cycles in sediments from basins and continental margins of the Eastern south Atlantic since
Early Cretaceous: IX Congrès Internat. de Sédimentologie, Nice.

Müller, C., 1974. Calcareous nannoplankton, Leg 25 (Western Indian Ocean). In Schleck, R., Roland, R., Initial Reports of the Deep Sea Drilling Project, Volume 25: Washington (U.S. Government Printing Office), p. 579-594.

Noël, D., 1968. Nature et genèse des alternances de marnes et de calcaires du Barrémien supérieur d'Angles. (Fosse vocontienne, Basses-Alpes): C. R. Acad. Sci. Paris, v. 266, p. $1223-1225$.

1970. Coccolithes crétacés. La craie campanieene du Bassin de Paris: 1 vol. Paris (Editions du CNRS).

Roth, P.H., Mullin, M.M., and Berger, W.H., 1975. Coccolith sedimentation by fecal pellets: laboratory experiments and field observations: Geol. Soc. Am. Bull., v. 86, p. 1079-1084.

Sweeney, R. E and Kaplan, I. R., 1973. Pyrite framboid formation: laboratory synthesis and marine sediments: Econ. Geol., v. 68, p. 618-634.

Wise, S. W., and Hsü, K. J., 1971. Genesis and lithification of a deep sea chalk: Eclog. Geol. Helv., v. 64, p. 273-278.

Wise, S. W. and Kelts, K. R., 1972. Inferred diagenetic history of a weakly silicified deep sea chalk: Gulf Coast Assoc. Geol. Soc. Trans., v. 22, p. 177-203. 



\section{PLATE 1}

Site 361

Figures 1-5 48-2, 141-144 cm. Dark bituminous shale. Lower Aptian ?. Scale bar $=1 \mu \mathrm{m}$.

1, 2. Coccolith impressions: Watznaueria are completely dissolved. $\times 5500$.

3. Carpeting of large octahedral crystals of pyrite. $\times 1100$.

4. Detail of the crystals. $\times 11,000$.

5. Pyrite framboids. $\times 11,000$. Note the difference in size between framboid crystals and crystals carpeting the sediment.

\section{PLATE 2}

Site 361

Figures 1-5 33-3, 76-77 cm. Dark gray shale with plant fragments. Upper Aptian. Scale bar $=1 \mu \mathrm{m}$.

1. Surface of sediment showing pyrite framboids in a crack and some coccoliths. $\times 2550$.

2. Details of pyrite framboids, the crystals of which are indistinct. $\times 6300$.

3. Details of coccoliths: well-preserved Watznaueria barnesae. $\times 6300$.

4. Cretarhabdus decussatus (Manivit) Stradner, 1968 (proximal side) partly broken. $\times 13,800$.

5. Watznaueria barnesae (Black) Perch-Nielsen, 1968 showing dissolution effects. $\times 13,800$.

(see p. 500)

\section{PLATE 3}

Site 361

Figures 1-4 33-3, 31-32 cm. Dark gray shale with very fine white laminae. Lower Albian. Scale bar $=1 \mu \mathrm{m}$.

1. Coccospheres remains, the coccoliths of which have not been scattered. $\times 5600$.

2. Details of coccoliths: Corolithion rhombicum (Stradner and Adamiker) Bukry (proximal side and distal side). $\times 11,300$.

3. Bipodorhabdus biforatus (Black) Barrier, 1977 (with its broken central process) in a cluster of coccoliths caked with clay. $\times 5500$.

4. Coccoliths (Zygolithus sp. Parhabdolithus asper). (Stradner) Reinhard, 1967, among clay particles. $\times 11,300$.

(see p. 501) 
Plate 1
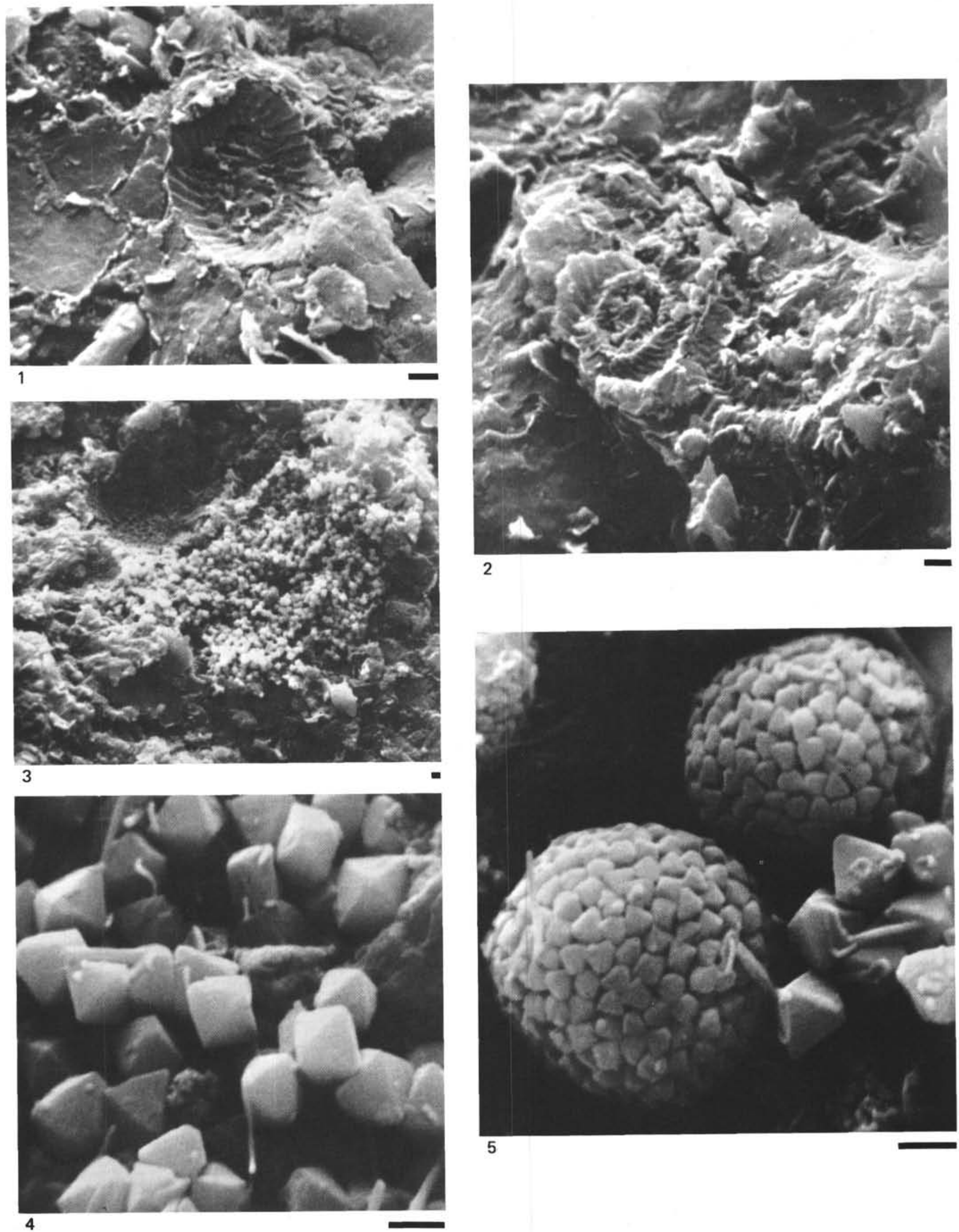


\section{PLATE 2}
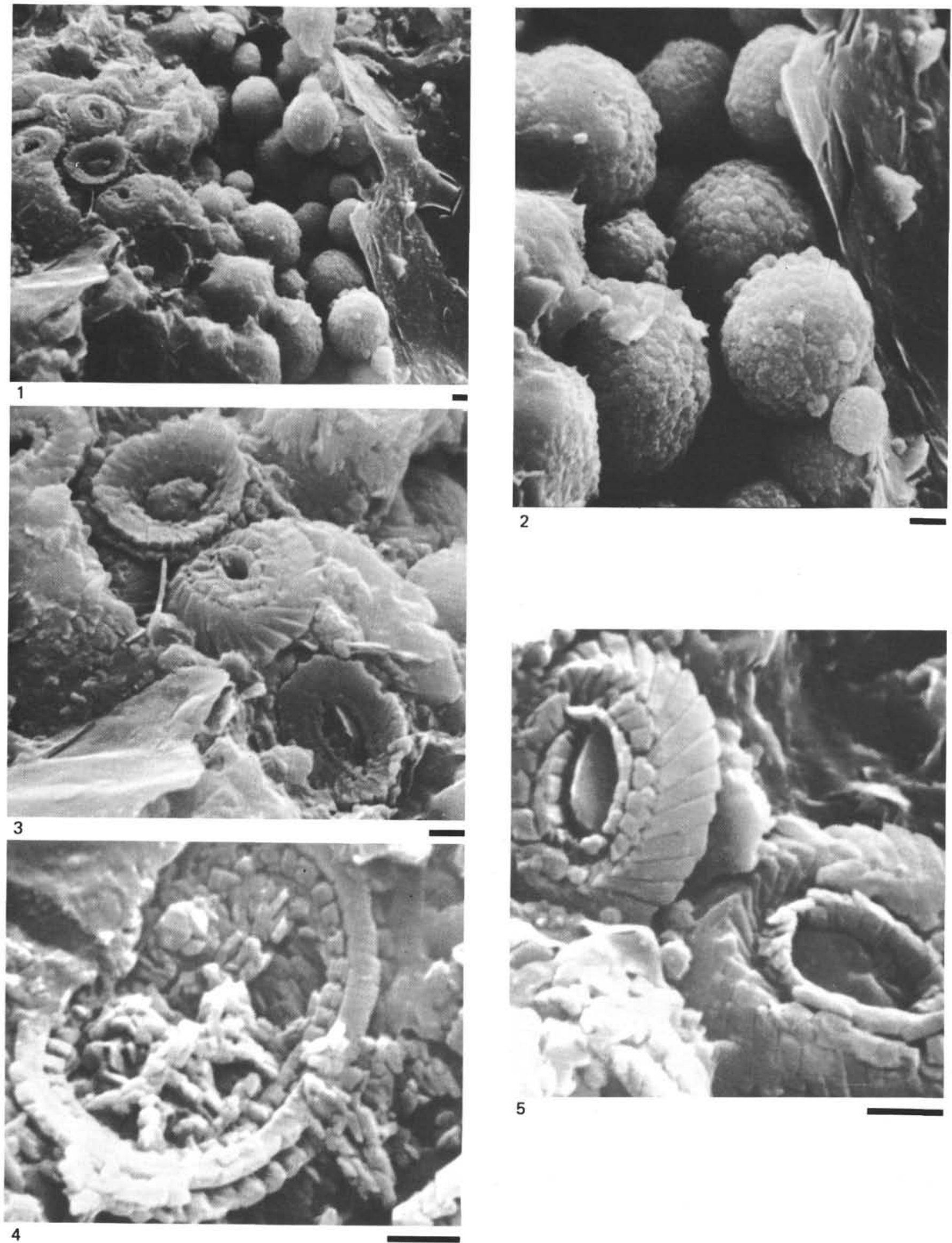
PLATE 3
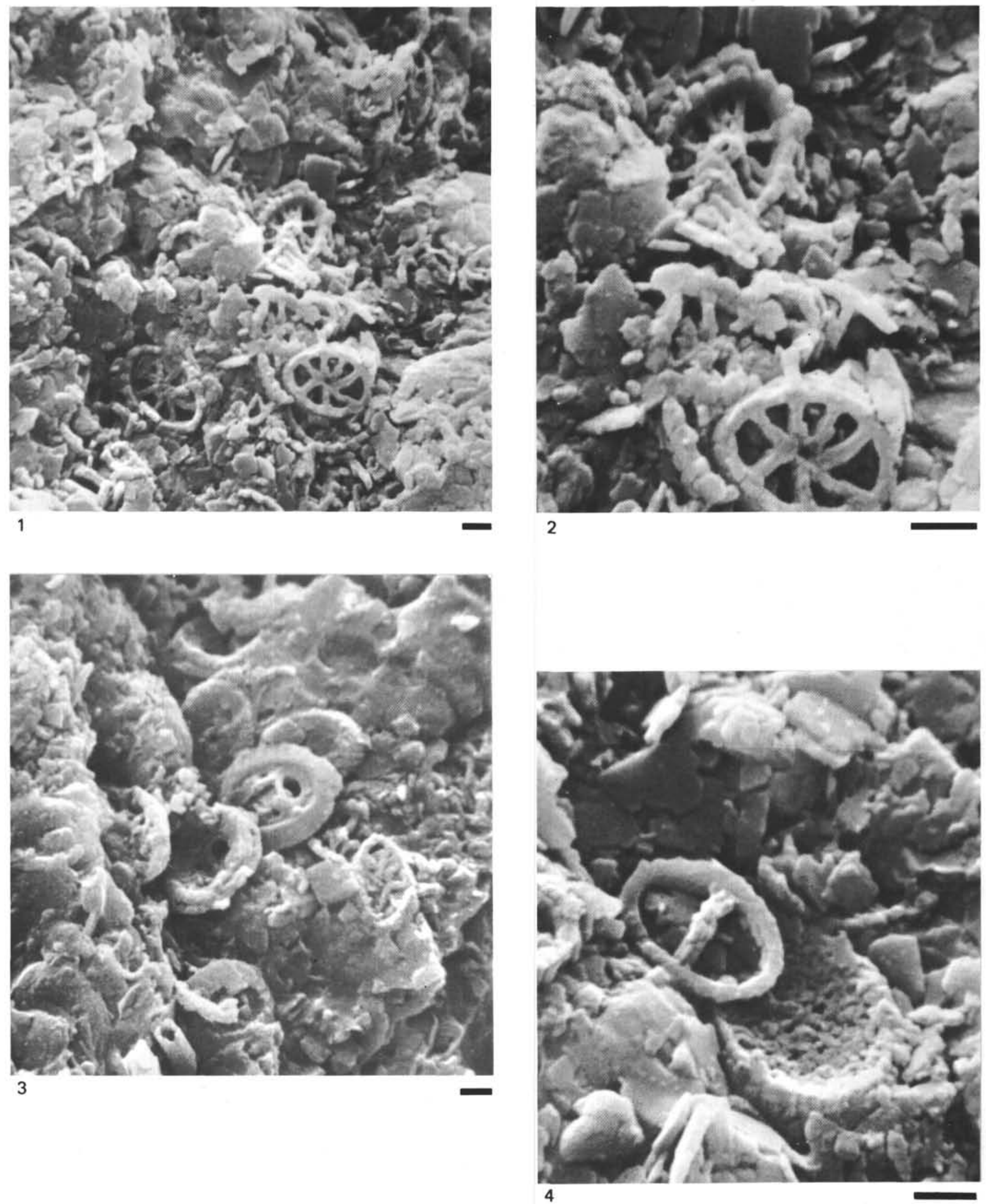


\section{PLATE 4}

\section{Site 361}

Figures 1-4 33-3, 31-32 cm. Lower Albian. White layer. Scale bar $=1 \mu \mathrm{m}$.

1. Fresh broken surface of the sediment showing numerous Nannoconus placed edge to edge. $\times$ 5000.

2. Details of a Nannoconus in cross-section. Note the shape of the elements which are very little joined. $\times 13,000$.

3. An area of sediment with Nannoconus completely dissociated into separate elements. $\times 13,000$.

4. Numerous Nannoconus in differently oriented sections and two Parhabdolithis asper, well preserved with their central processes. $\times 6500$.

\section{PLATE 5}

Site 361

Figure 1

$32-3,119-121 \mathrm{~cm}$. Dark gray silty clay with plant remains. Lower/upper Albian. $\times 6000$. Scale bar $=1 \mu \mathrm{m}$.

Figure $2 \quad 32-1,24-25 \mathrm{~cm}$. Dark gray unlaminated mudstone. Lower-upper Albian. Scale bar $=1 \mu \mathrm{m}$. Ooze with pyrite framboids and partly dissolved Watznaueria. $\times 6000$.

Figures $3,4 \quad 31-3,74-76 \mathrm{~cm}$. Dark gray silty mudstone with plant debris. Lower-upper Albian. Coccosphere remains; coccoliths are not scattered. (Parhabdolithus asper ?). $\times 6000$. Scale bar $=1 \mu \mathrm{m}$.

(see p. 504)

\section{PLATE 6}

Site 361

Figures 1-3, 5 31-3, 59-61 cm. Dark gray coarse silt. Lowerupper Albian. Scale bar $=1 \mu \mathrm{m}$.

1. Coccosphere remains of Parhabdolithus asper, the coccoliths of which are more or less preserved. $\times 11,000$.

2. Portion of a coccosphere of Watznaueria barnesae. $\times 6000$.

3. Cluster of different coccoliths: Cretarhabdus crenulatus, Corolithion rhombicum, Watznaueria parvidentata (Deflandre) Bukry. $\times 12,000$.

5. Another cluster of coccoliths (more broken). $\times$ 6000 .

Figure 4 26-6, 139-141 cm. Chocolate brown shale. Upper Albian. Scale bar $=1 \mu \mathrm{m}$. Ooze with coccoliths strongly plastered with clay. $\times 16,000$.

Figure $6 \quad 28-3,98-99 \mathrm{~cm}$. Dark gray shale. Upper Albian. Scale bar $=1 \mu \mathrm{m}$. Well-crystallized clay. (Kaolinite). $\times 5000$. 
PLATE 4
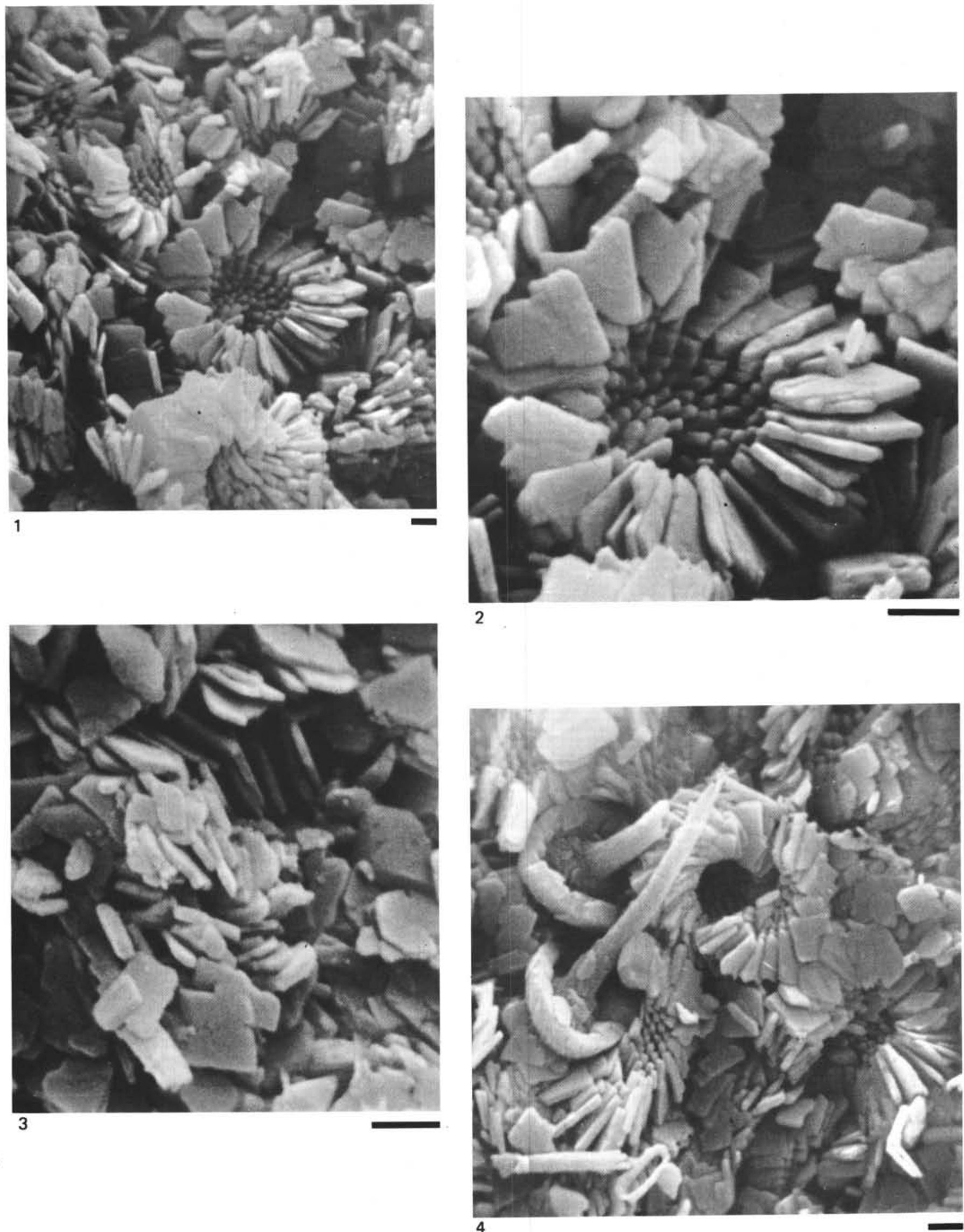


\section{PLATE 5}
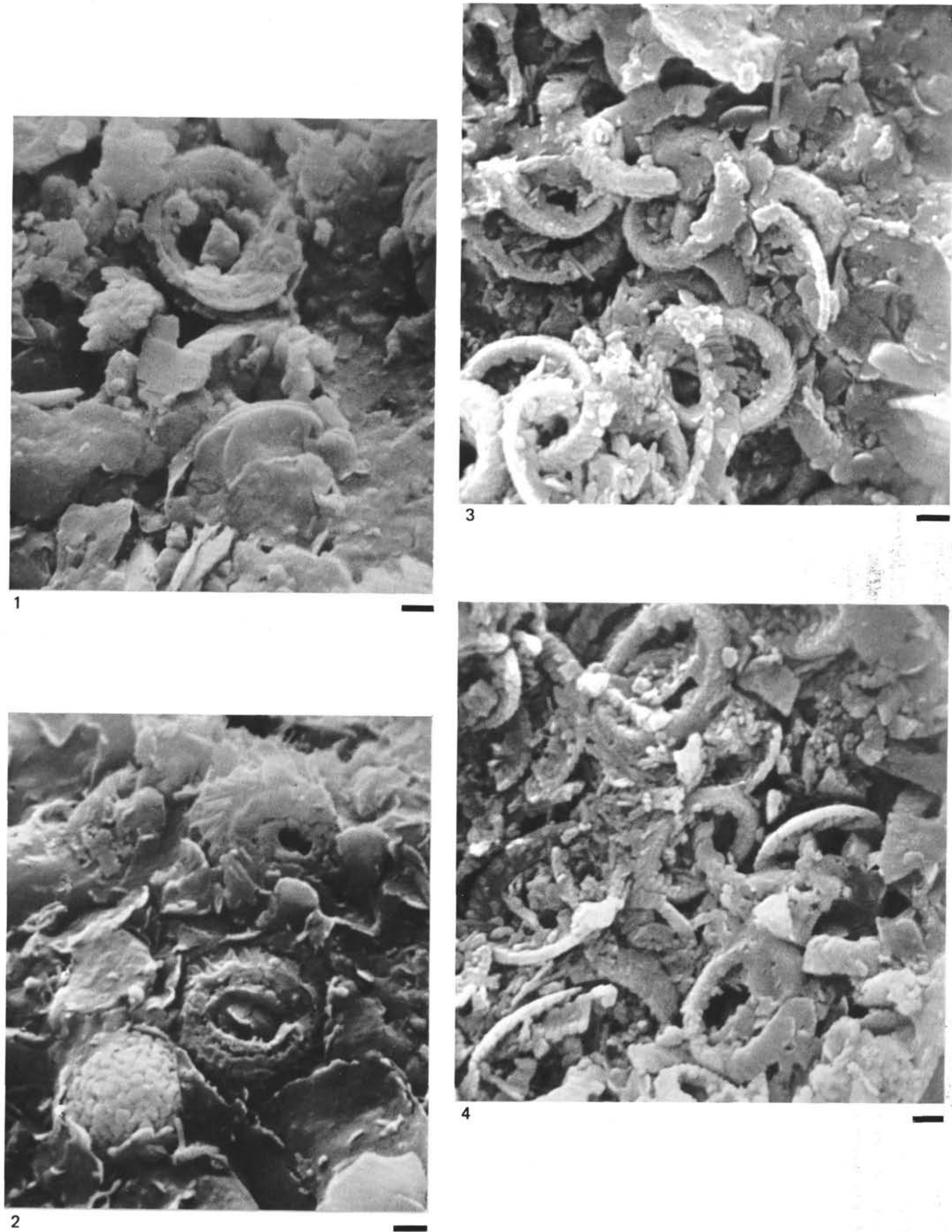
PLATE 6
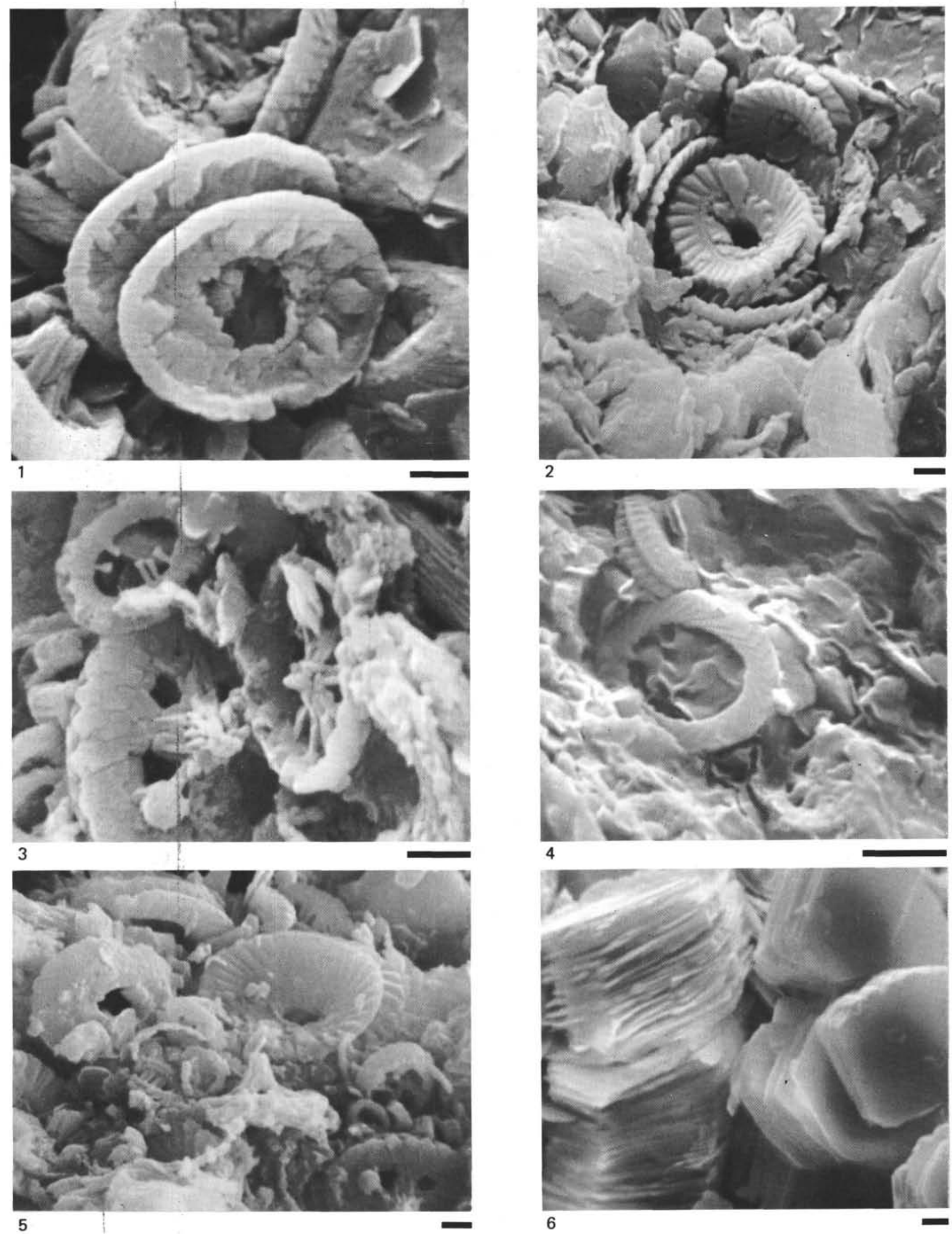


\section{PLATE 7}

Site 361

Figure 1

Figure 2

Figure 3

Figure 4

Figure 5

Figure 6

\section{PLATE 8}

Site 361

Figures 1-3 7-1, 139-140 cm. Bluish-gray marly mud. Lower $/$ middle Eocene. Scale bar $=1 \mu \mathrm{m}$. Nanno ooze with coccoliths strongly caked with clay.
1. $\times 4200$.
2. $\times 5500$
3. $\times 2200$.

Figures 4-6 6-2, 62-63 cm. Bluish-gray marly mud. Middle Eocene. Scale bar $=1 \mu \mathrm{m}$. Nanno ooze with the same nannofacies as above.
4. $\times 5000$.
5. $\times 2000$.
6. $\times 5300$. 


\section{PLATE 7}
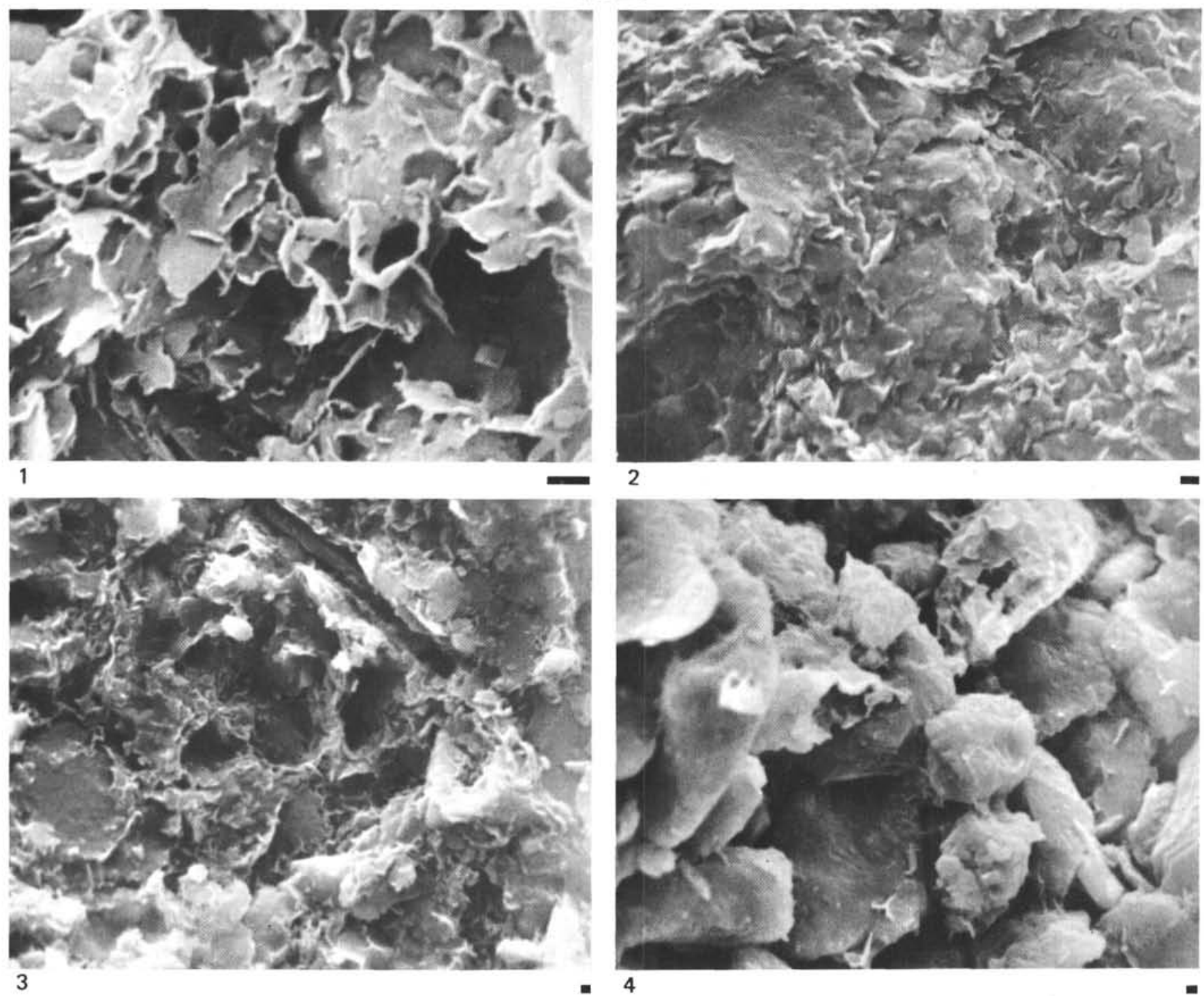

3

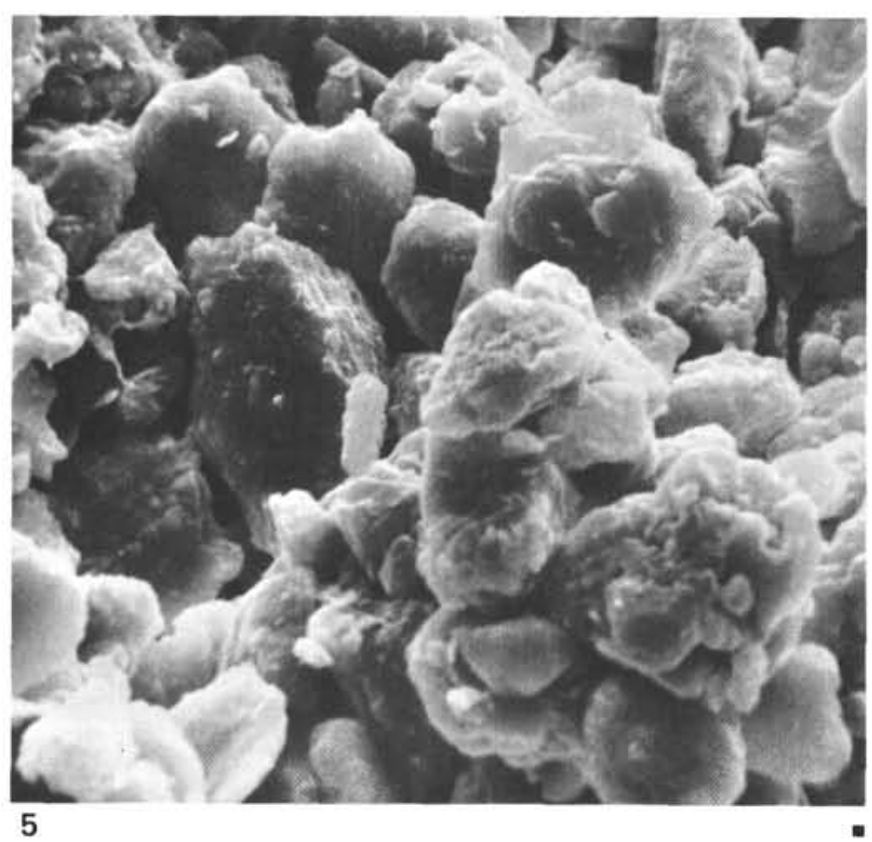

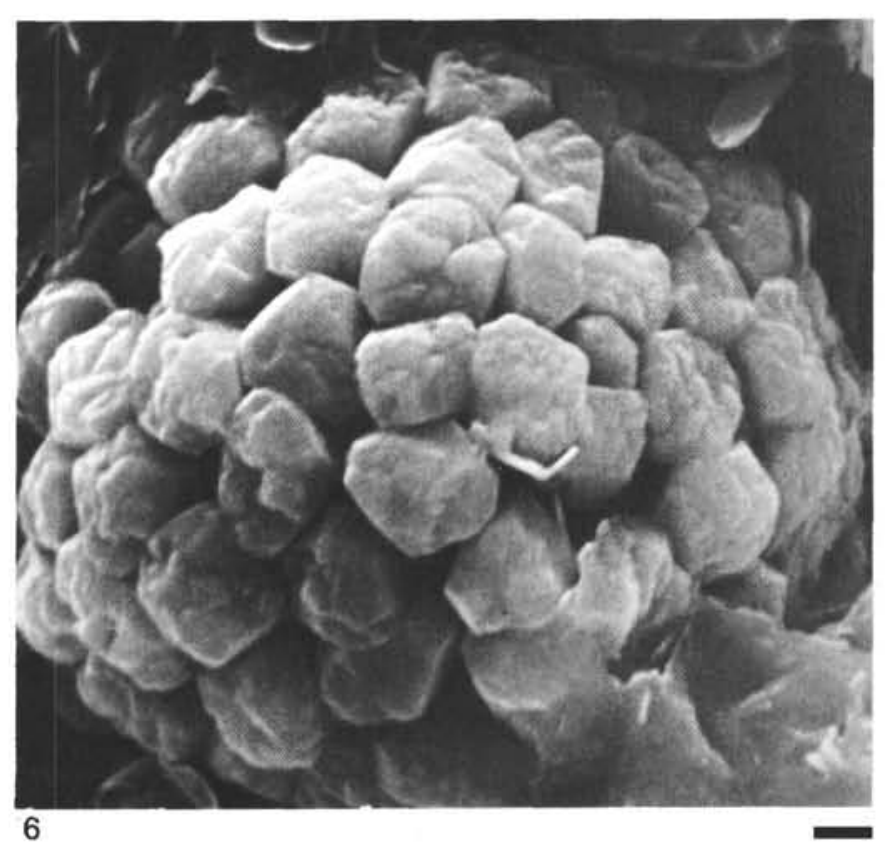




\section{PLATE 8}
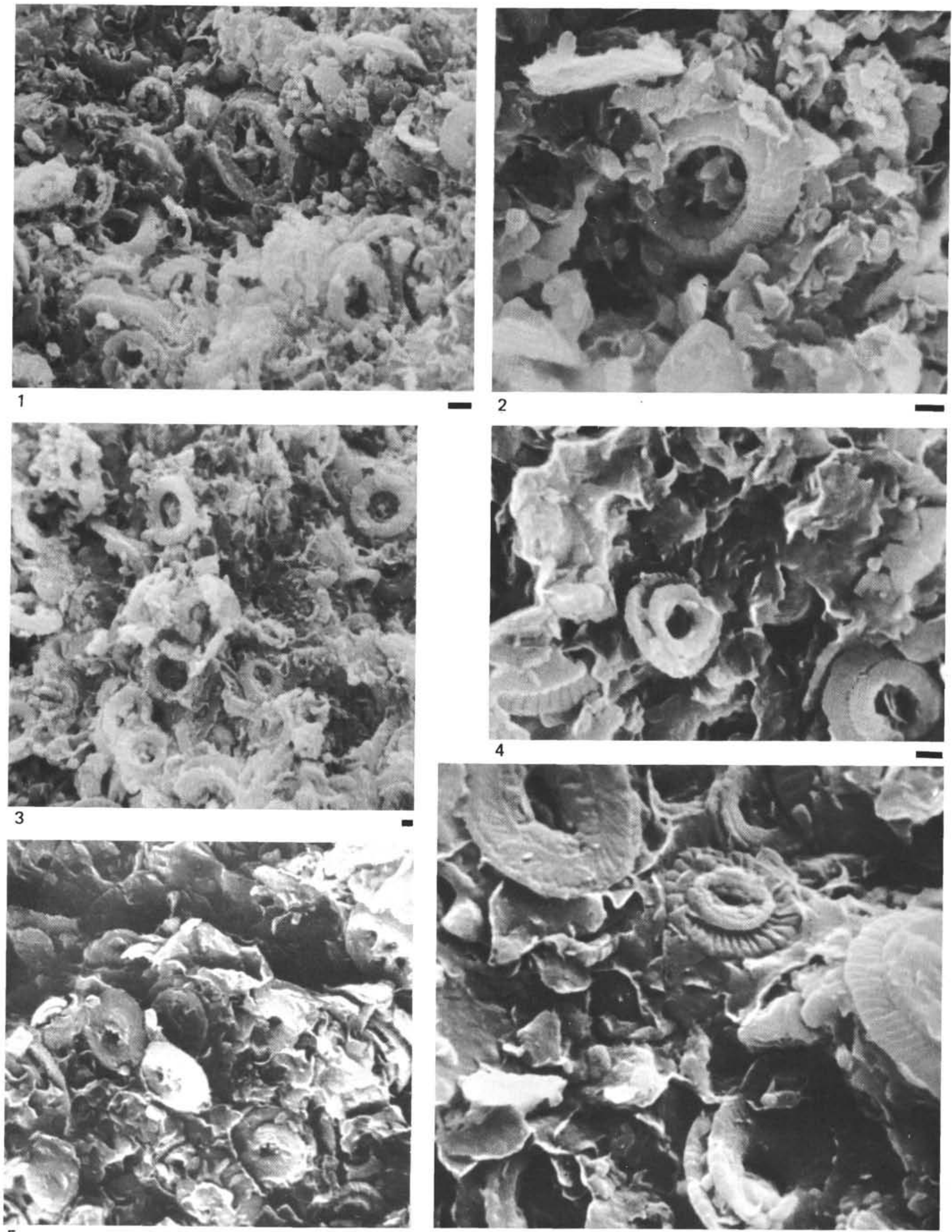

-
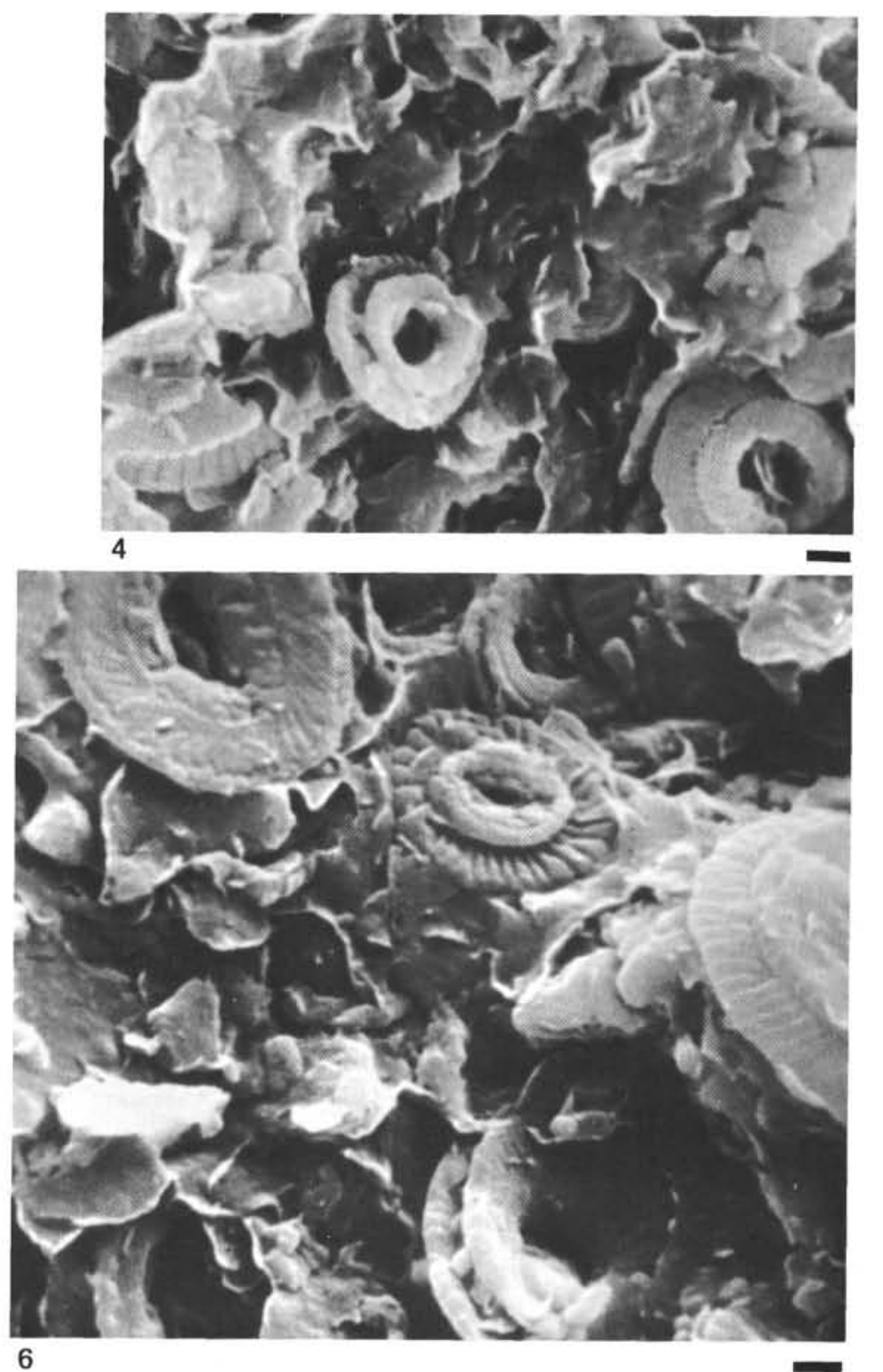


\section{PLATE 9}

Site 360

Figures 1, $2 \quad 50-1,139-141 \mathrm{~cm}$. Marly greenish-gray limestone. Middle Eocene. Scale bar $=1 \mu \mathrm{m}$. Nanno ooze with coccoliths strongly caked with clay as Plate 8.

1. $\times 2600$.

2. $\times 6500$.

Figure $346-4,139-141 \mathrm{~cm}$. Marly greenish-gray limestone. Middle Eocene. Scale bar $=1 \mu \mathrm{m}$.

Figures 4, $5 \quad 44-2,139-141 \mathrm{~cm}$. Marly greenish-gray limestone. Middle Eocene. Nanno ooze with large clean coccoliths. Scale bar $=1 \mu \mathrm{m}$.

(see p. 510)

\section{PLATE 10}

Site 360

Figures 1-3 34-1, 139-141 cm. Marly limestone. Lower Oligocene. Scale bar $=1 \mu \mathrm{m}$.

1. Well-preserved coccoliths of Coccolithus eopelagicus (Bramlette and Riedel) Bramlette and Sullivan, 1961. $\times 6500$.

2. Clean coccoliths on a piece of foraminifers. $X$ 2600.

3. $\times 6500$.

Figures 4, 5 44-2, 139-141 cm. Marly limestone. Middle Eocene. Scale bar $=1 \mu \mathrm{m}$.

4. Large well-preserved coccolith of Reticulofenestra bisecta (Hay, Mohler, and Wade)'Roth (proximal side) among fragments of coccoliths and clay particles. $\times 6500$.

5. Chiasmolithus altus Bukry and Percival, 1971, (distal side) and Reticulofenestra bisecta (distal side) with clean structures. $\times 5500$.

(see p. 511) 
PLATE 9
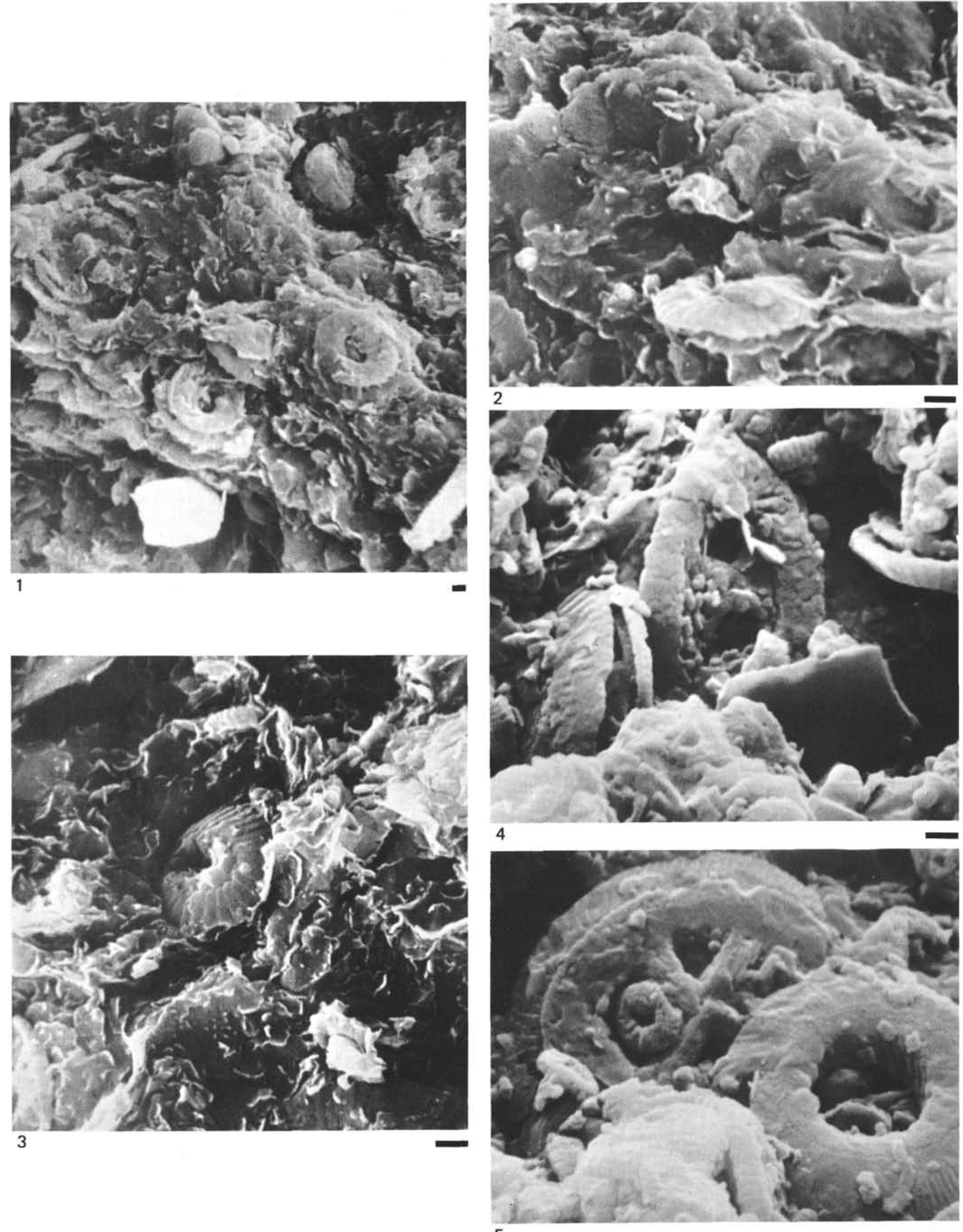
PLATE 10
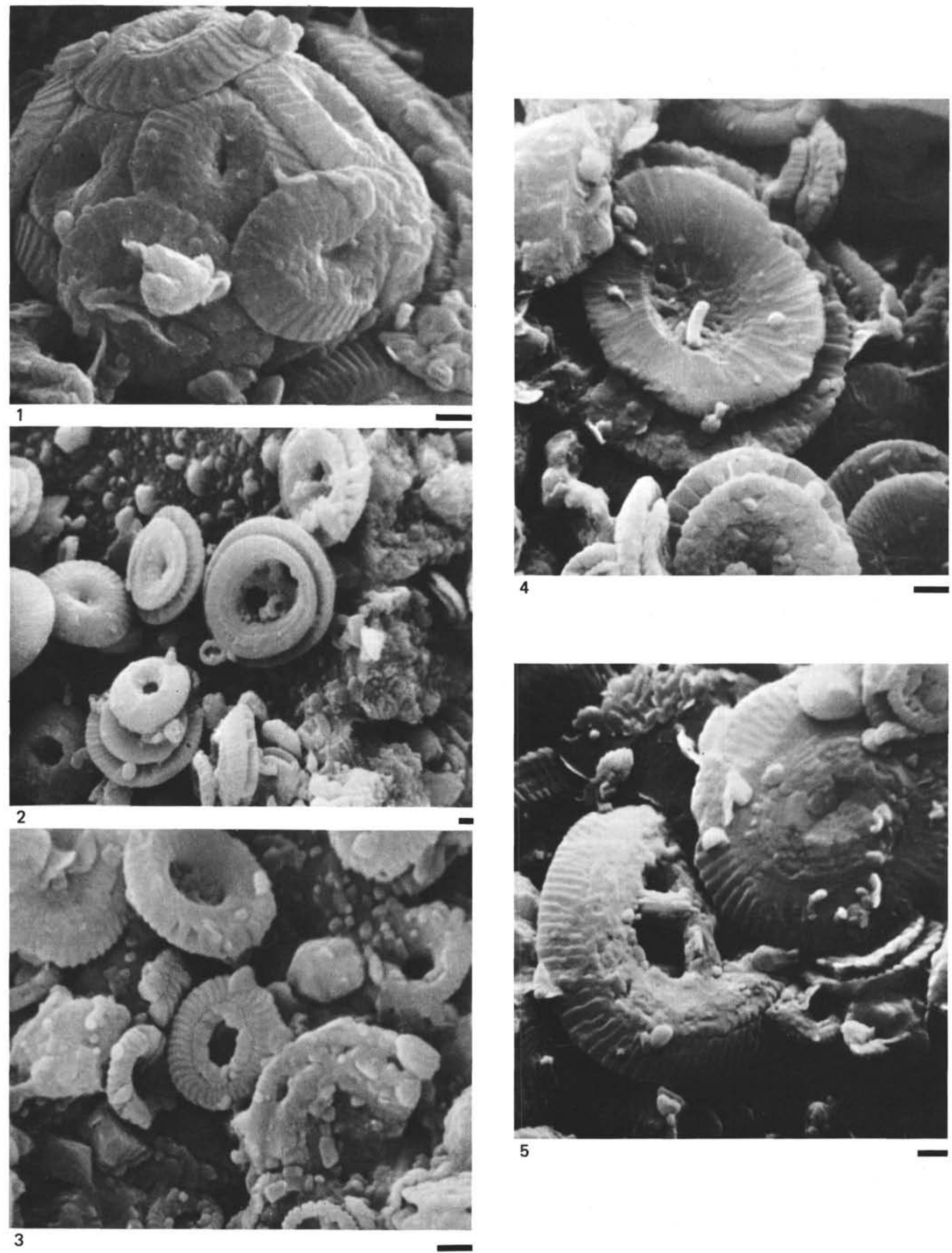


\section{PLATE 11}

Site 360

Figures 1-3 19-2, 139-141 cm. Middle Miocene. Scale bar = $1 \mu \mathrm{m}$. Nanno ooze with large placoliths among nannofossil fragments and very small clay particles. Note that structures of coccoliths are caked with clay and therefore not clearly perceptible.

1, $2 \times 2900$

3. $\times 2200$.

Figures 4, $5 \quad 33-5,139-141 \mathrm{~cm}$. Lower Oligocene. Scale bar $=$ $1 \mu \mathrm{m}$.

4. Nanno ooze with coccoliths sometimes in cluster. $\times 6000$.

5. Chiasmolithus altus Bukry and Percival 1971. $\times$ 6000. Compare the aspect of nannofacies of the two series of pictures. At left, clay strongly caking nannofossils; At right, clean coccoliths.

\section{PLATE 12}

Site 360

Figures 1, $3 \quad 33-11,139-141 \mathrm{~cm}$. Light to medium gray marly chalk. Lower Pliocene. Scale bar $=1 \mu \mathrm{m}$.

1. Cluster of coccoliths with clay particles. $\times$ 6200.

3. Discoaster calcaris Gartner, 1967, well preserved. Between arms, salt crystals. $\times 6200$.

Figures 2-4 8-3, 139-141 cm. Light to medium gray marly chalk. Upper Miocene. Scale bar $=1 \mu \mathrm{m}$. Whole entire coccospheres with some dissolution marks. $\times 6000$.

Figure $5 \quad 10-3,139-141 \mathrm{~cm}$, Light to medium gray marly chalk. Upper Miocene. Scale bar $=1 \mu \mathrm{m}$. Nanno ooze with placoliths and fragments among clay particles. $\times 4000$.

Figure $6 \quad$ Same as samples above. Helicosphaera kamptneri strongly dissolved. $\times 12,000$.

(see p. 514) 
PLATE 11
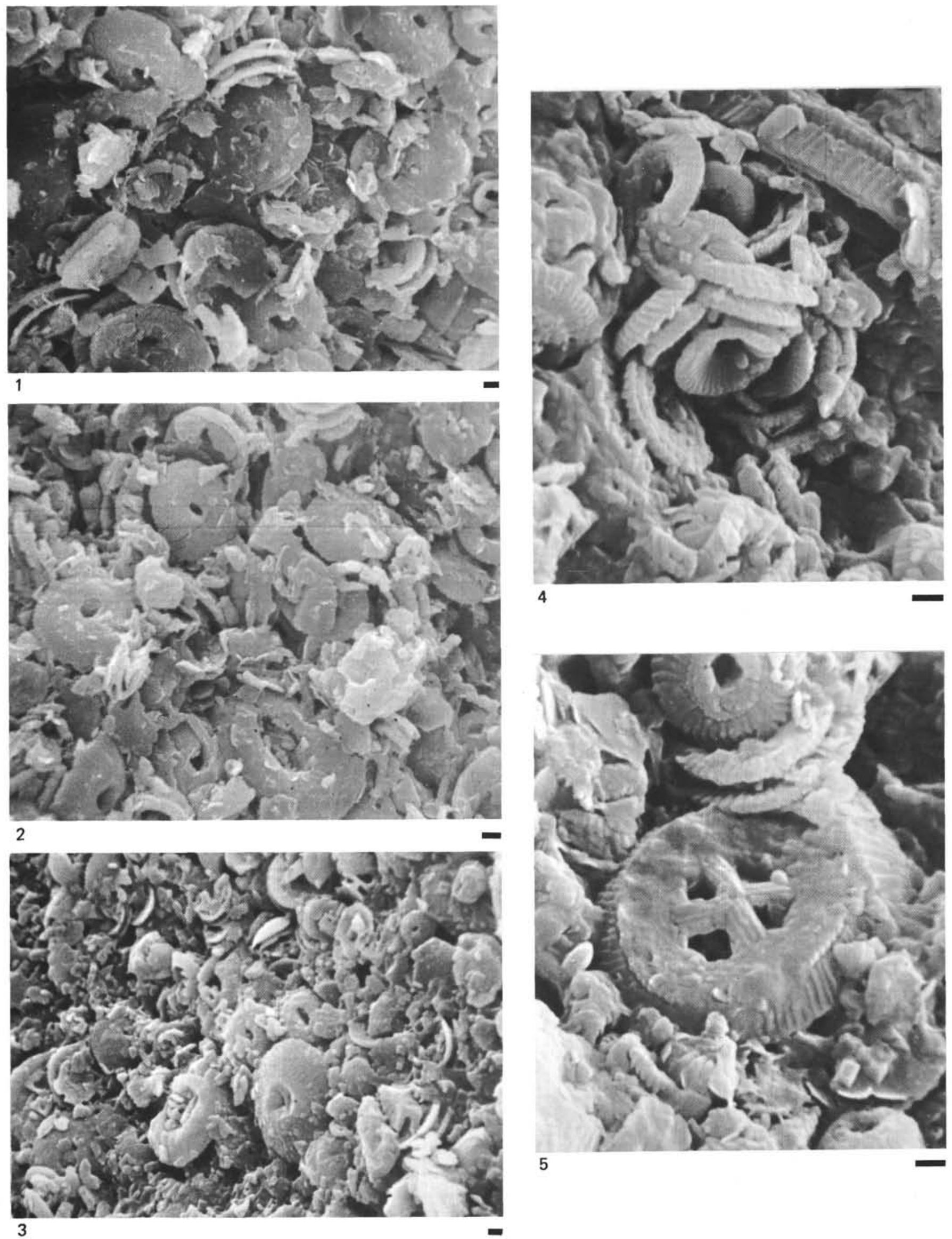


\section{PLATE 12}
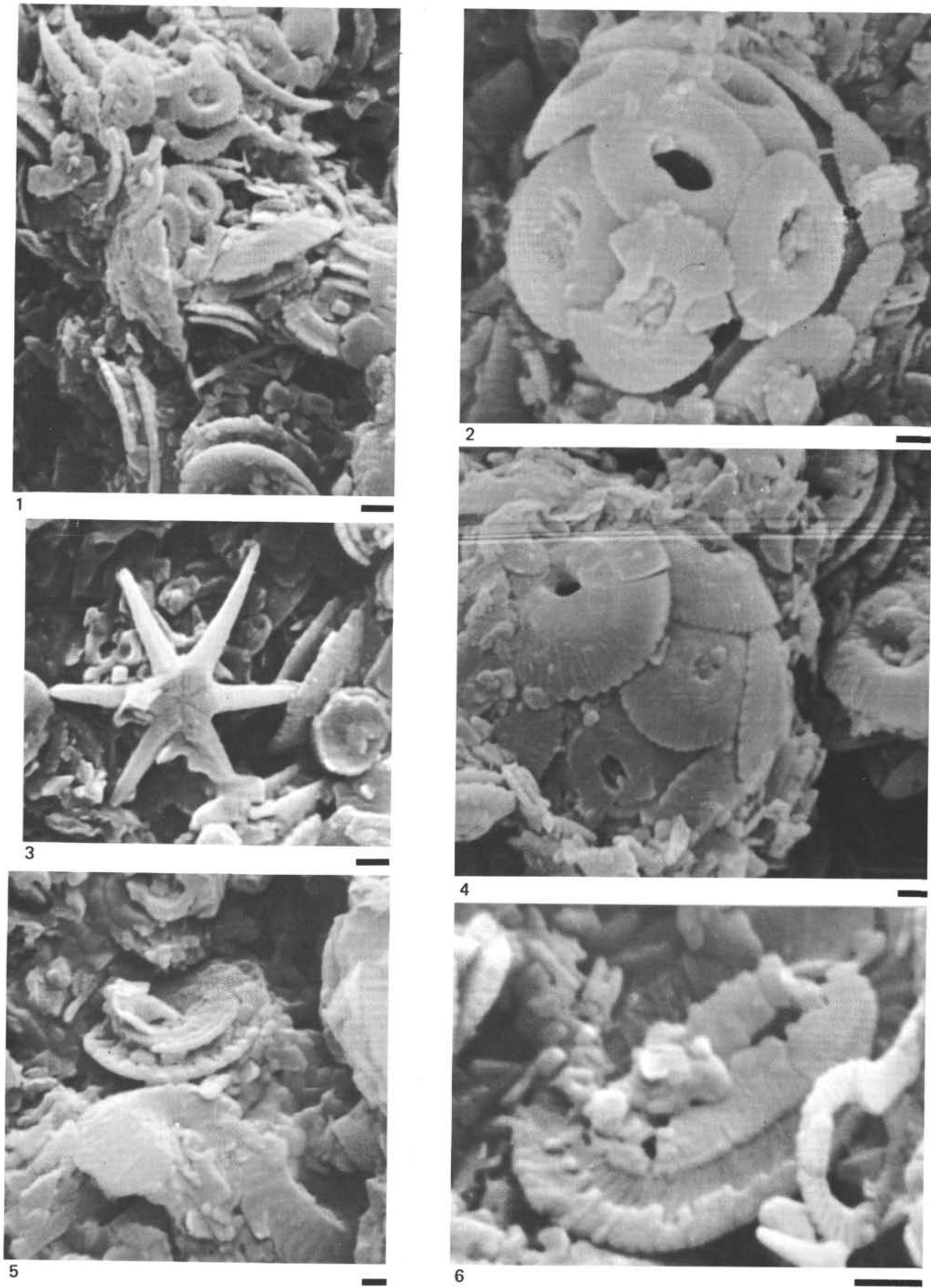
PLATE 13

Hole 362

Figure $1 \quad 5-5,114-116 \mathrm{~cm}$. Light gray very fine mud. Oligocene. Scale bar $=1 \mu \mathrm{m}$. Lithified chalk with a coccosphere of Coccolithus eopelagicus and other placoliths among with calcite crystals. $\times 2800$.

Figure $25-3,60-62 \mathrm{~cm}$. Light gray very fine mud. Oligocene. Scale bar $=1 \mu \mathrm{m}$.

Same type of nannofacies: large placoliths showing overgrowth effects among with numerous large calcite crystals. $\times 6800$.

Figure $3 \quad 5-1,86-88 \mathrm{~cm}$. Light gray very fine calcareous mud, highly indurated. Oligocene. Scale bar $=1 \mu \mathrm{m}$. $\times 6800$.

Figures 4-6 9-1, 122-124 cm. Very fine, homogeneous limestone of light gray color. Middle Eocene. Scale bar $=1 \mu \mathrm{m}$.

Lithified limestone with large calcite crystals and spherules of crystoballite forming the cement of the sediment.

4. $\times 2400$,

5. Details, $\times 6000$.

6. $\times 3000$.

(on the left side of the picture Discoaster tani Bramlette and Riedel, 1954).

(see p. 516)

PLATE 14

Hole $362 \mathrm{~A}$

Figures 1, $2 \quad 8-4,31-33 \mathrm{~cm}$. Greenish gray-light green $/$ calcareous mud. Highly indurated. Middle Eocene. Scale bar $=1 \mu \mathrm{m}$.

Marly limestone showing nannofossils strongly caked with clay. $\times 2900$.

Figures $3,4 \quad 5-2,54-56 \mathrm{~cm}$. Dark gray fine marly mud. Oligocene. Scale bar $=1 \mu \mathrm{m}$.

Marl with numerous placoliths. (Cyclicargolithus floridanus) (Roth and Hay) Bukry, 1971. ×6500.

(see p. 517) 


\section{PLATE 13}
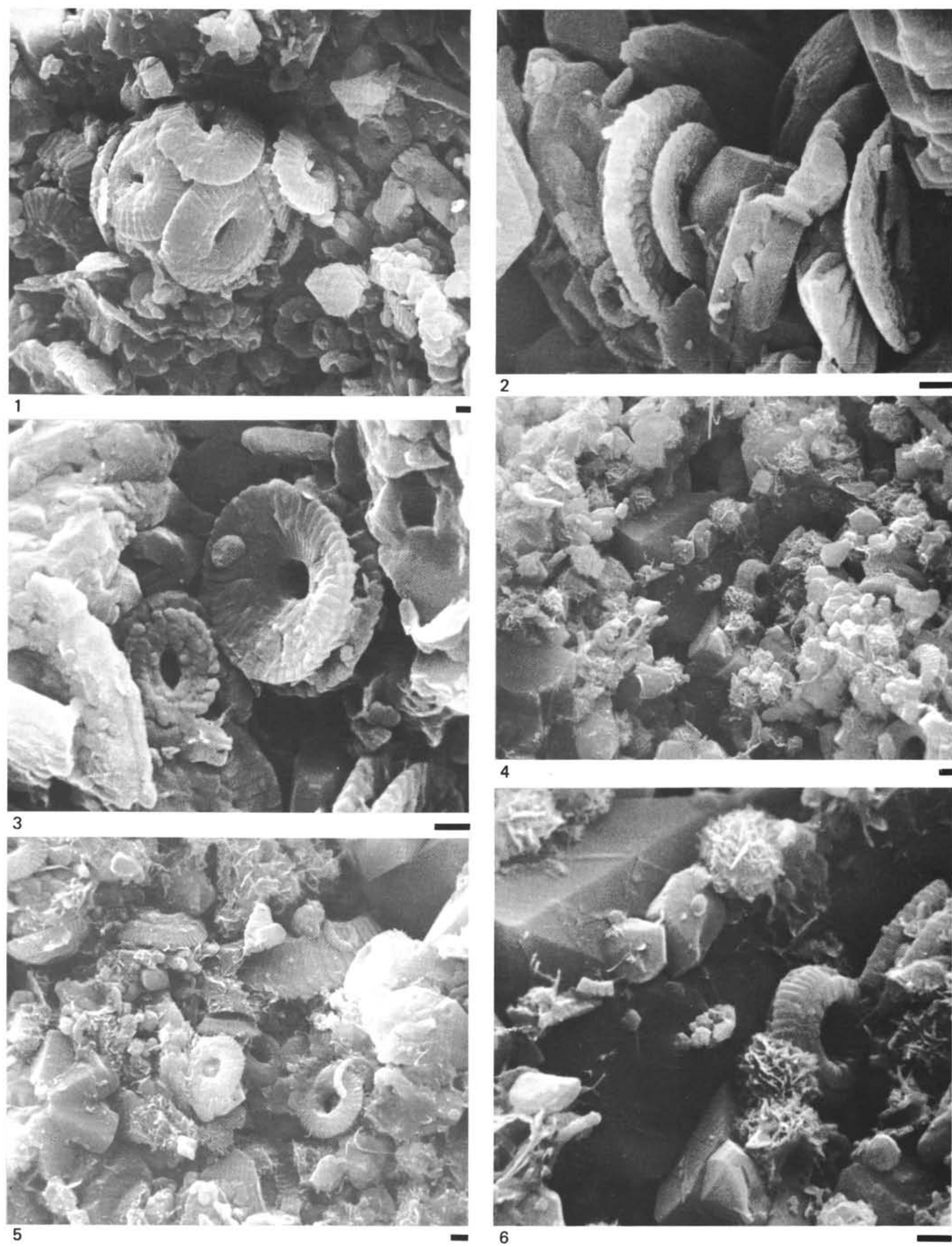


\section{PLATE 14}
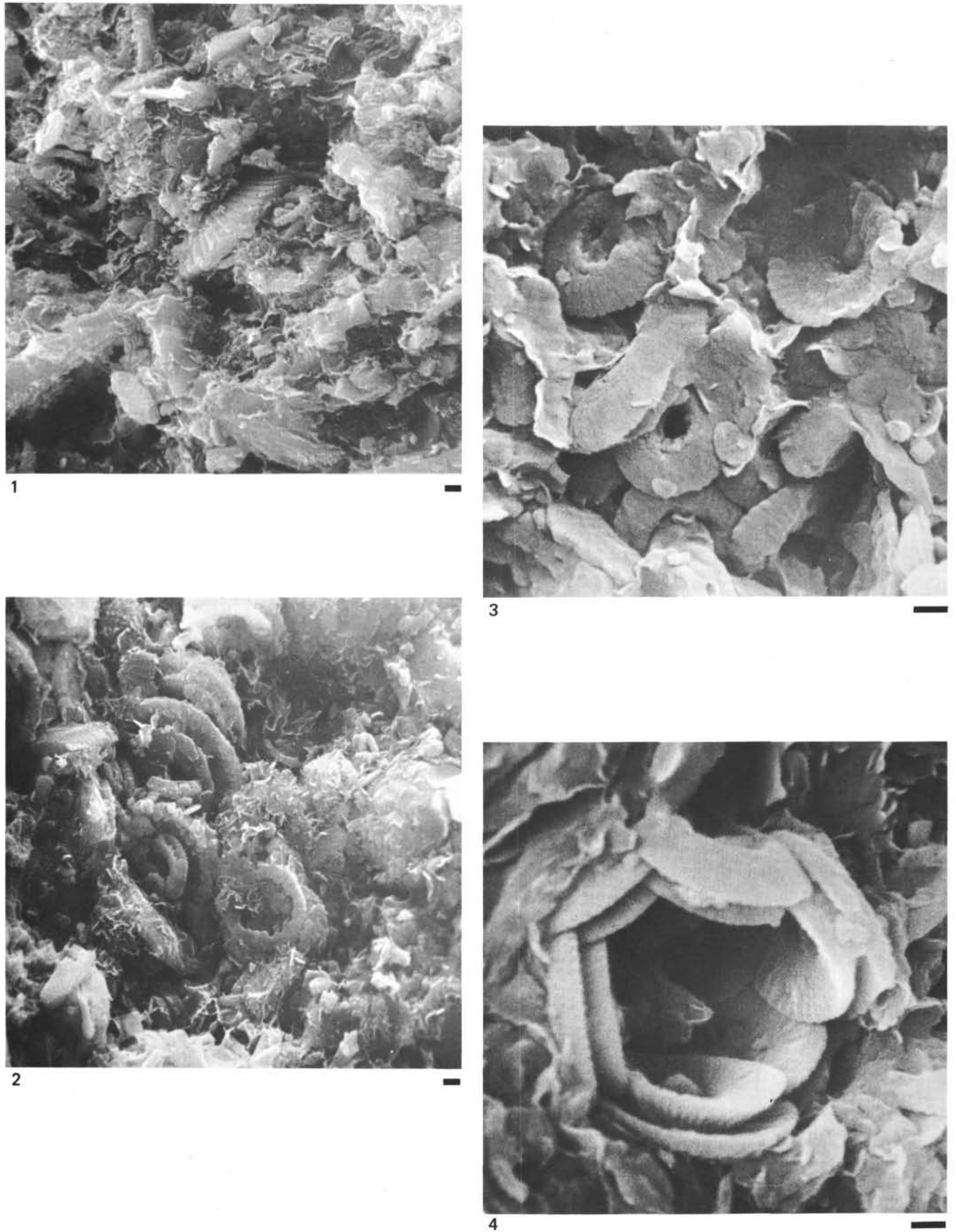
PLATE 15

Hole $362 \mathrm{~A}$

Figures 1, $2 \quad 4-6,81-83 \mathrm{~cm}$. Highly indurated calcareous zone. Middle Oligocene. Scale bar $=1 \mu \mathrm{m}$.

Limestone built up nannofossils (Figure 1, coccosphere of Cycloccolithus formosus) and large crystals of secondary calcite. $\times 6700$.

Figure $34-5,69-71 \mathrm{~cm}$. Middle Oligocene. Scale bar $=5 \mu \mathrm{m}$. Layer with numerous broken foraminifers. $\times 280$.

Figure $4 \quad 4-4,146-148 \mathrm{~cm}$. Medium gray, very fine, mud. Middle Oligocene. Scale bar $=1 \mu \mathrm{m}$.

Marl with cluster of coccoliths in a argillaceous matrix. $\times 6500$.

PLATE 16

Hole 362A

Figures 1-3 4-3, 53-55 cm. Light olive-gray fine mud. Middle Oligocene. Scale bar $=1 \mu \mathrm{m}$.

1. Mosaic of pictures showing a curious layer with only one species (Reticulofenestra bisecta). The coccoliths are oriented in a similar manner, on their proximal side. $\times 2500$.

2. Other sample area with distal sides of $R$. bisecta. $\times 2500$.

3. Part of Figure 1 at higher magnification. $\times 6250$.

(see p. 520)

\section{PLATE 17}

Figure 1 362A-3-6, 149-151 cm. Middle Oligocene. Compacted marl. $\times 6100$. Scale bar $=1 \mu \mathrm{m}$.

Figures 2-4 362-41-6, 135-141 cm. Upper Oligocene/lower Miocene. Scale bar $=1 \mu \mathrm{m}$.

Compacted marl with amorphous clayed areas.

2. $\times 2400$.

3. $\times 6600$.

4. $\times 6100$.

Figure $5 \quad 362-35-1,139-141 \mathrm{~cm}$. Lower-middle Eocene. $\times 6700$. Scale bar $=1 \mu \mathrm{m}$.

Note the similarity between the pictures showing the persistency of a marly sedimentation throughout middle Oligocene, lower/middle Eocene. 


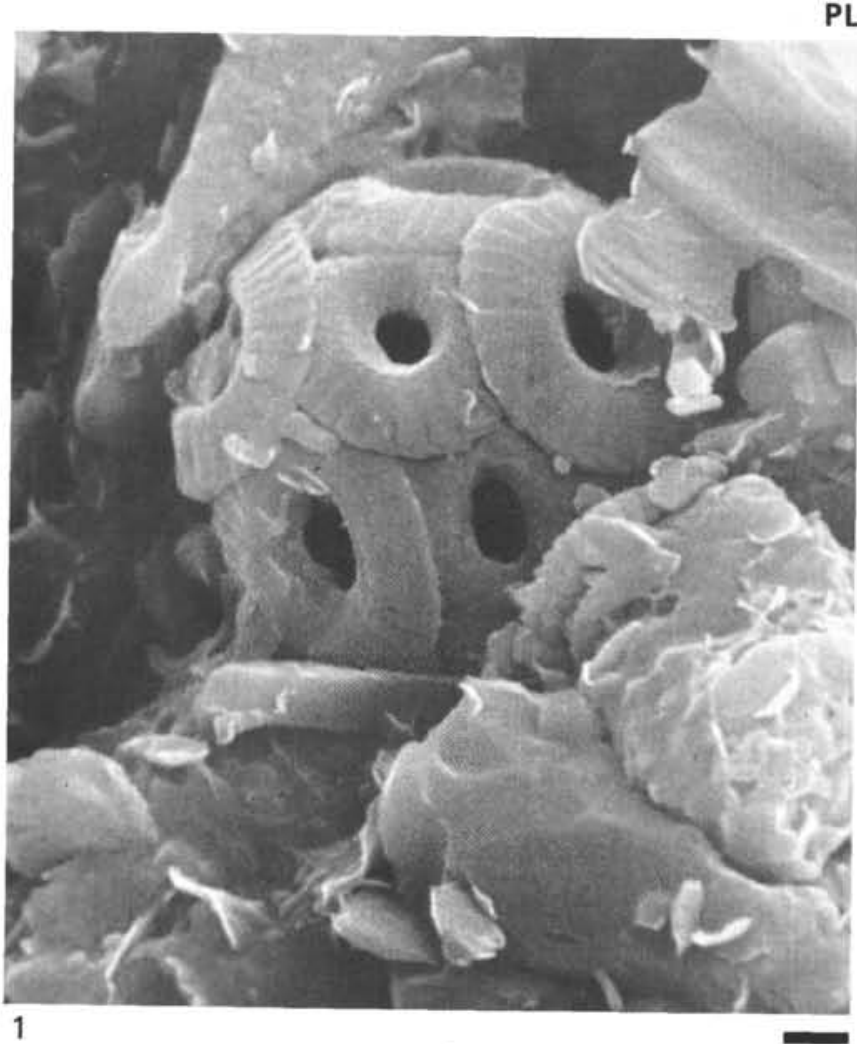

\section{PLATE 15}
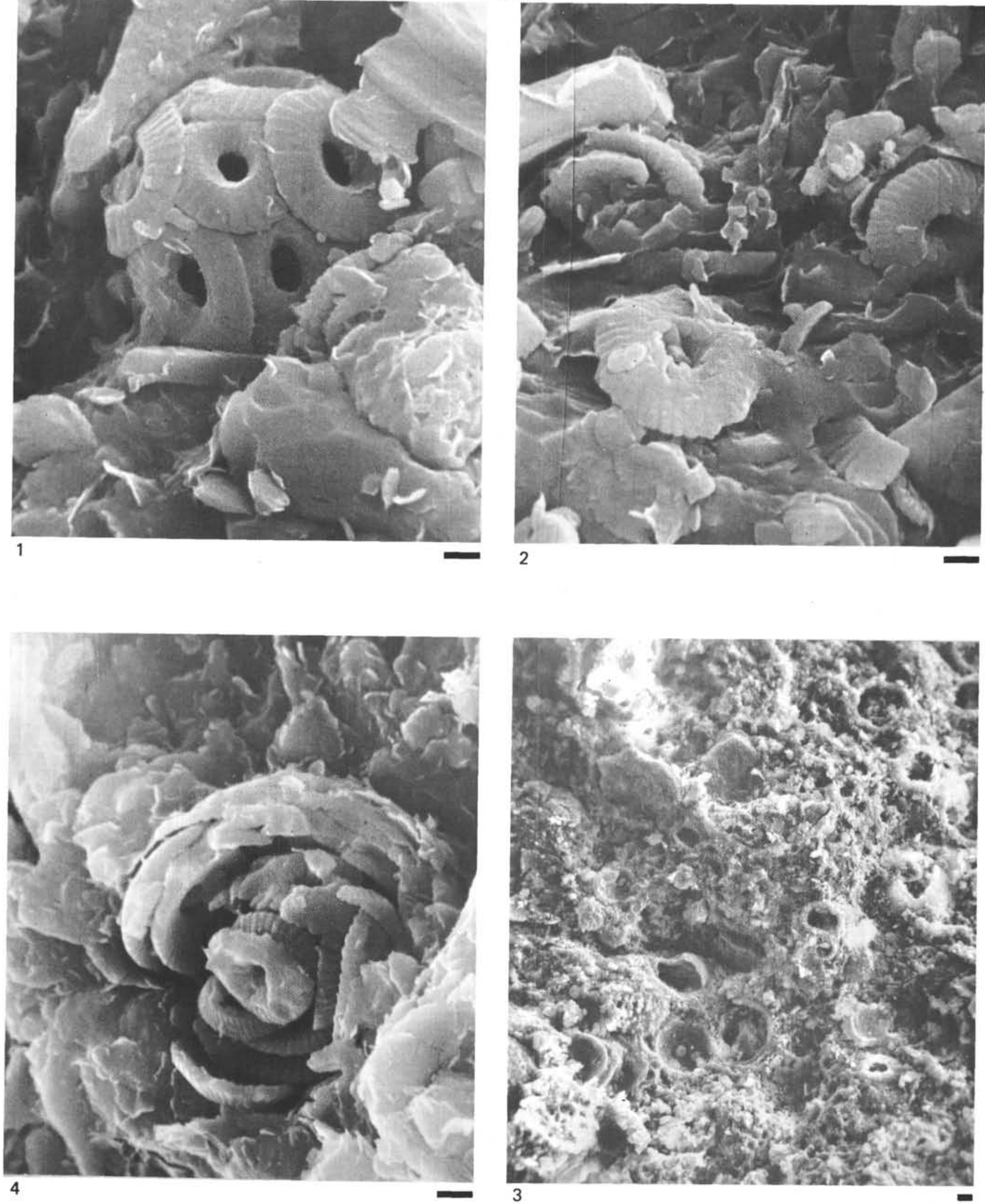


\section{PLATE 16}
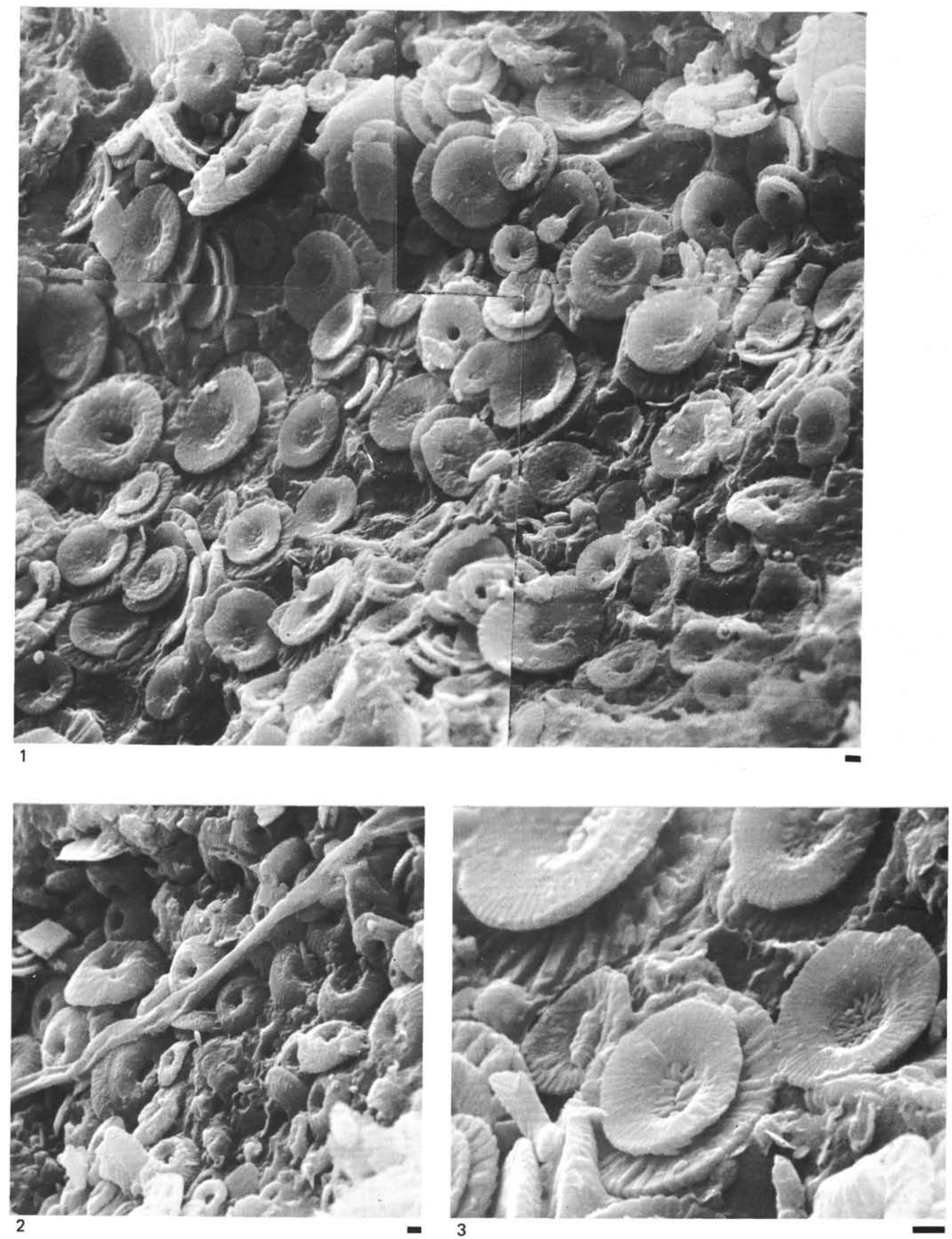
PLATE 17
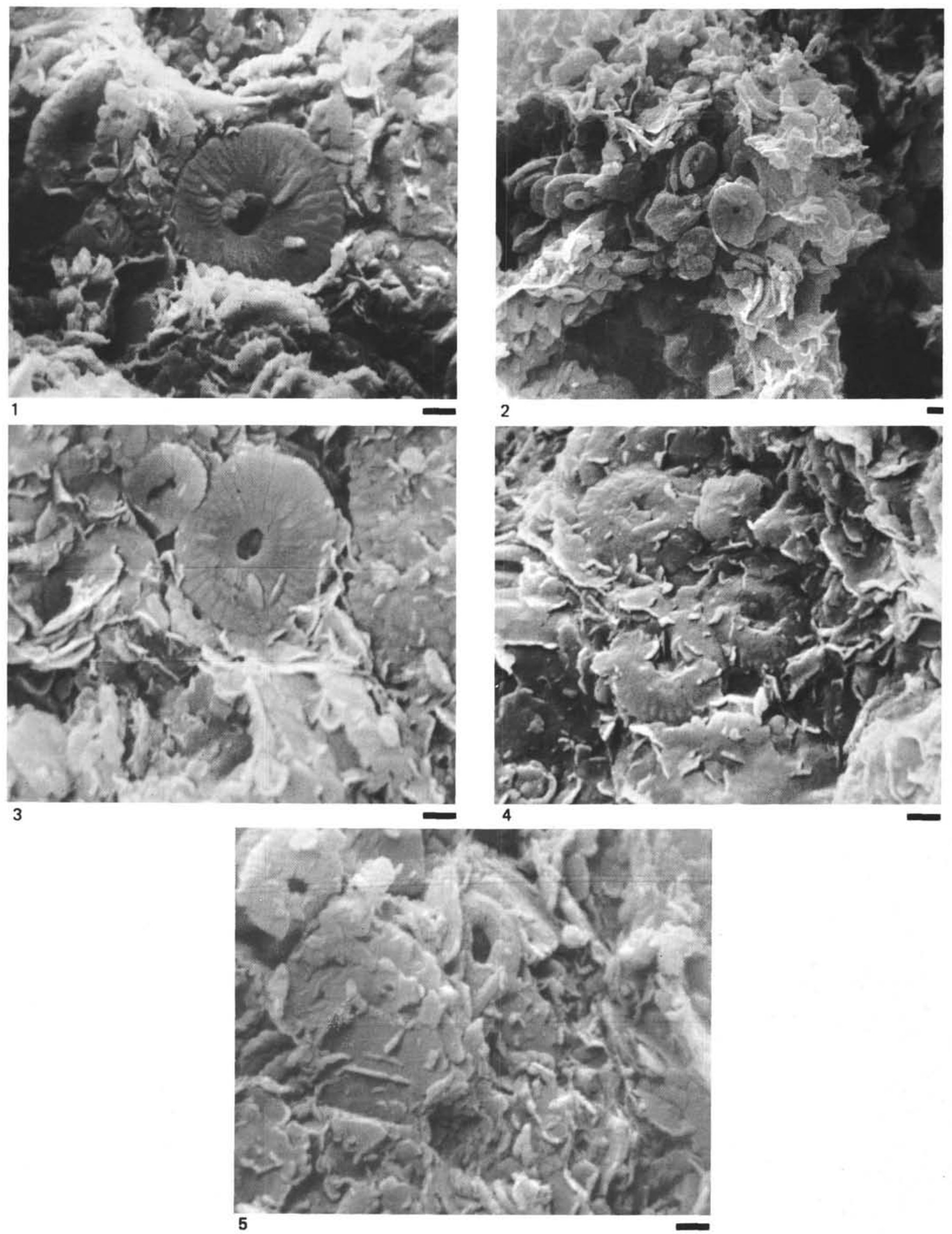
PLATE 18

Hole 362

Figures 1-4 26-1,139-141 cm. Green-gray marly chalk. Upper Miocene. Scale bar $=1 \mu \mathrm{m}$.

1. Partly dissolved radiolarians and numerous nannofossils. $\times 1350$.

2. At higher magnification: Cyclococcolithus macintyrei Bukry and Bramlette and a rhabdolith (?Discosphaera tubifer). $\times 6700$.

3. Area with damaged placoliths. In the center a distal shield (on proximal side) of Cyclococ $C_{-}$ colithus leptoporus. $\times 6700$.

4. A broken coccosphere seen from inside. $\times 6700$.

Figures 5, $6 \quad 21-1,139-141 \mathrm{~cm}$. Green-gray marly chalk. Upper Miocene. Scale bar $=1 \mu \mathrm{m}$. Areas with damaged nannofossils.

5. $\times 6400$.

6. $\times 5000$

\section{PLATE 19}

Figures 1-3 Site 363. Braarudosphaera chalk. Lower Oligocene. Scale bar $=1 \mu \mathrm{m}$.

1. 7-1, 139-141 cm. Braarudosphaera showing strong overgrowth effects among broken pieces. $\times 2400$.

Figures 2, 3 7-1, CC. "Braarudosphaera chalk." Lower Oligocene. Scale bar $=1 \mu \mathrm{m}$.

2. Placolith heavily affected by overgrowth. $\times 20,000$.

3. Braarudosphaera chalk with some entire pentaliths. $\times 2200$.

Figures 4-6 364-42-2, 9-10 cm. Black shales interbedded in marly limestones. Upper Aptian coccoliths in an argilo-bituminous matrice. Scale bar $=1 \mu \mathrm{m}$.

4. Coccosphere remains. $\times 6500$. (Watznaueria barnesae).

5. Zygolithus sp., a side view and on proximal side. $\times 2600$.

6. Coccolith print. $\times 6500$.

(see p. 524) 
PLATE 18
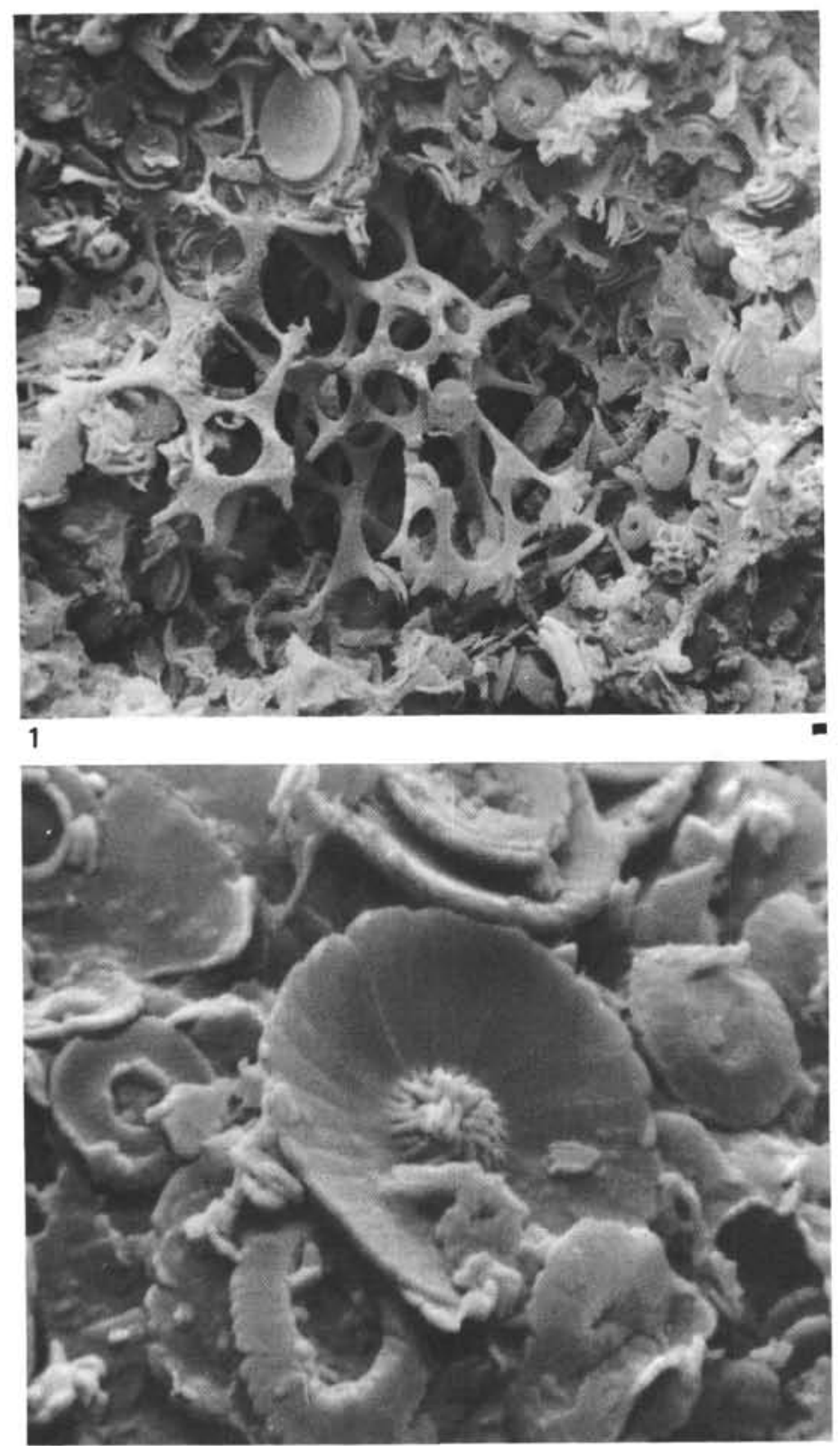

3

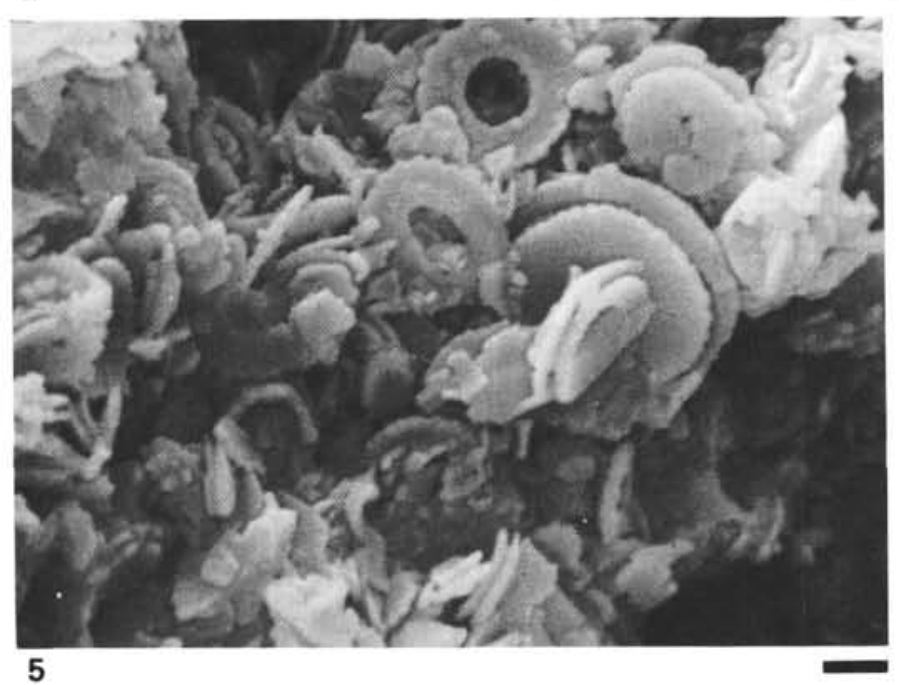



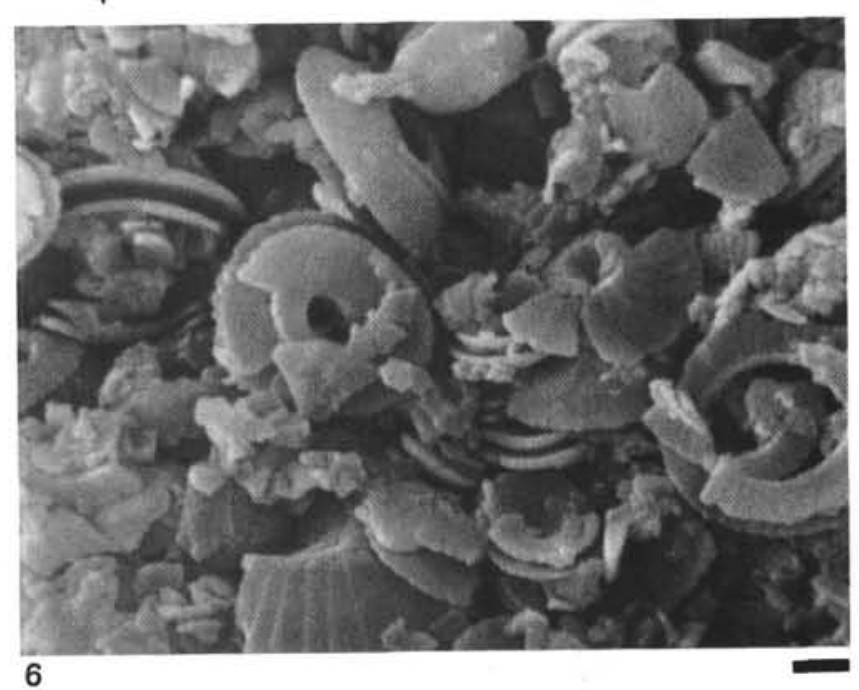


PLATE 19
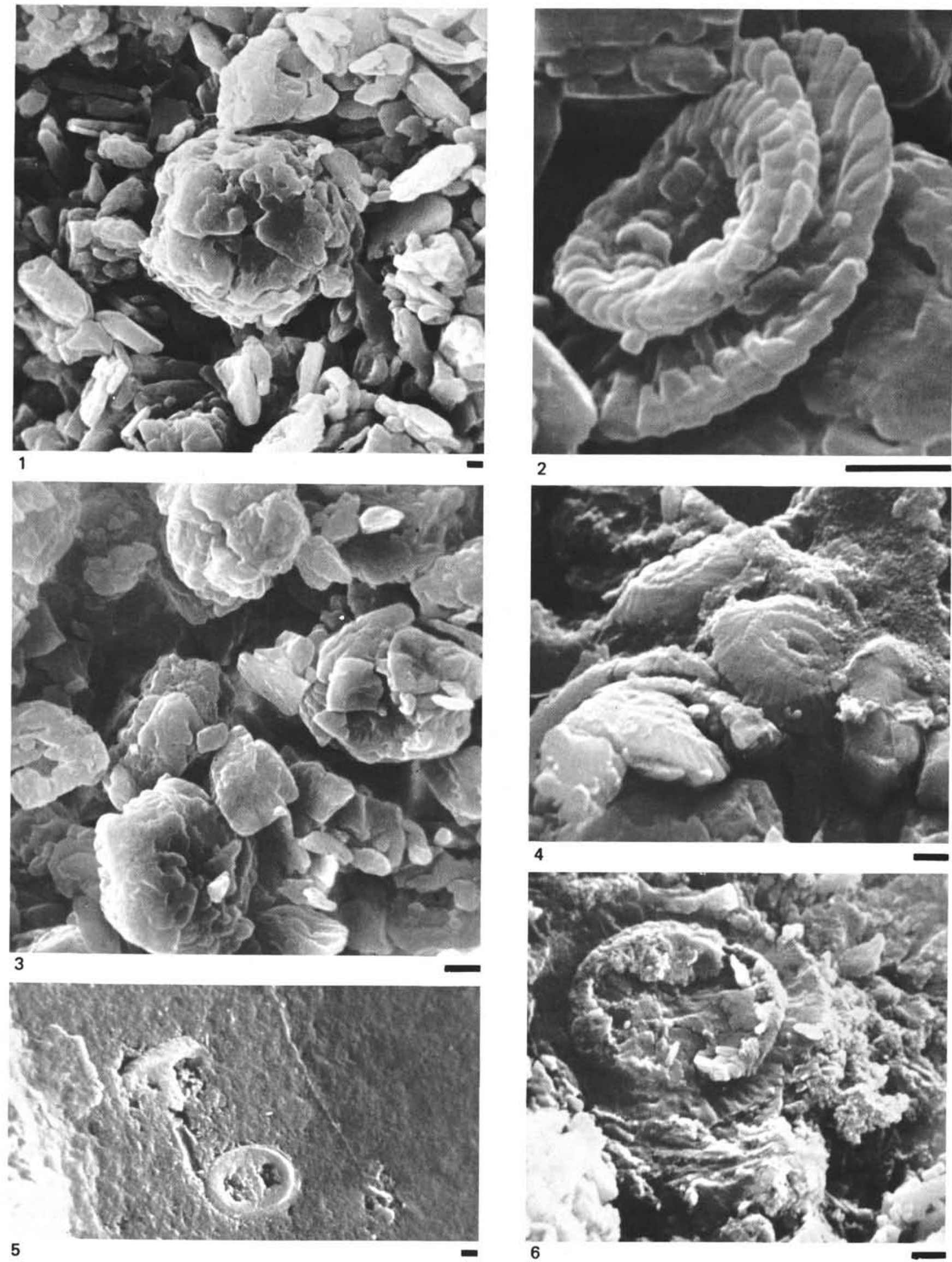